\title{
Turkish cinema
}

\author{
Nezih Erdoğan
}

Deniz Göktürk

\section{The first years}

Cinema, as a Western form of visual expression and entertainment, did not encounter resistance in Turkey, a country culturally and geographically bridging East and West. It perfectly represented the ambivalent attitudes of the national / cultural identity under construction. On one hand, cinema came as a sign of modernization / Westernization, not only for the images of the West being projected onto the screen, but also for the conditions of its reception. Cinematography was a technological innovation imported from the West and the ritual of going to the movies became an important part of the modern urban experience. On the other hand, cinema offered possibilities for the production of a 'national discourse'. Many of the early feature films reflect the 'birth of a nation' or resistance to the Allied Forces during World War I. The audience was already familiar with the apparatus (theatre, screen, figures, music and sound, light and shadow), which bore some resemblance to the traditional Turkish shadowplay Karagöz, one of the most popular entertainment forms of the past.

Ayse Osmanoğlu, the daughter of Sultan Abdülhamid II, remembers that the French illusionist of the palace used to go to France once a year and return with some novelties to entertain the palace population; a film projector throwing lights and shadows on a wall was the most exciting of these spectacles. The first public exhibition took place in 1896 or 1897 in the Sponeck pub, which was frequented by non-Muslim minorities (namely Levantines), as well as Turkish intellectuals infatuated with the Western civilization in Pera (today Beyoğlu), a district in the European part of Istanbul known for its cosmopolitan character. The film, probably projected by a $\mathrm{D}$. Henri, was the sensational L'arrivée d'un train en Gare (Lumière brothers, 1895). Ercüment Ekrem Talu, a famous writer and journalist of the time who was present in the audience, reports how the flickering image of a train approaching the camera scared away the viewers, an effect similar to that experienced by the audience at the Grand Café in Paris in 1895.

It was Sigmund Weinberg, a Polish Jew from Romania, who organized the first regular commercial screenings as the authorized exhibitor of Pathé and Lumière films. In 1908 he began to run the first movie theatre - Pathé. In order to outflank his competitors, he continually upgraded the projection machines, showed longer films with better image quality, and hired someone to stand up during the projection and explain the meaning of what the audience saw.

Until recently the first film to be shot by an Ottoman citizen was generally accepted to be Ayastefanos Abidesinin Ylkulș̦l / The Demolition of the Monument St Stephen 
(1914) by Fuat Uzkınay, an army officer who had taken an interest in cinematography. Curiously, this film is not thought to have survived and it is unclear whether it ever existed. A recent discovery suggests that it was the brothers Milton and Yanaki Manaki (Ottoman citizens of Greek origin, who feature in Ulysses' Gaze by Theo Angelopolous 1995)) who made the first Ottoman film in 1911. Their film showed Sultan Reshad V arriving at Bitolia.

Just before 1915 the infamous General Enver had spent some time in Germany, where he observed the propaganda value of newsreels. When he became the minister of defence in 1915, he gave orders to establish a film department in the army. Weinberg served as head of the department, filming military, royal and other official visits, as well as Enver's much-admired horses and new-born babies. Weinberg had to quit when Romania and Turkey declared war on each other. His assistant, Uzkinay, having learned all the tricks of the trade from Weinberg, took over the department and continued to make war documentaries. Weinberg, after two unsuccessful attempts, completed the feature film Himmet A ganın İzdivacı / The Marriage of Himmet Agha (1916). A young journalist, Sedat Semavi, followed with two features: Pençe / The Claw (1917) and Casus / The Spy (1917). The veteran stage actor and director Ahmet Fehim made three films: Mürebbiye / The Governess (1919), Binnaz (1919) and Bican Efendi Vekilharç / Custodian Bican (1921). These were mostly adaptations from stage or literature, and the stars were either amateurs or professional players from the theatre.

\section{The domination of theatre and the first 'cinematographers'}

After the founding of the Republic in 1923, a nationalist discourse that had already been gaining power in the final years of the Ottoman Empire was disseminated directly by the state, aiming to legitimize a transition from ummet (from umma, meaning the Islamic community or population) to millet (from mille, meaning nation). This transition also brought about a conscious distancing from other Islamic countries that had been part of the Empire for centuries. It further led to a romanticizing admiration for 'contemporary [that is, Western] civilization' which, despite all its imperialist and colonialist attitudes, promised technological progress and offered a model for a better political structure, especially secularism. The films that were made in those years display both an effort to construct a national identity and the heavy influence of the West.

Muhsin Ertuğrul represents the 'cinema' of the newly founded Republic. He was mainly a man of the theatre, but also employed his resources in a wide range of cinematic attractions, such as multinational productions, colour films and adaptations. Turkish film historians define an opposition between a group of film-makers coming from the theatre (Refik Kemal Arduman, Talat Artemel, Mümtaz Ener, Kani Kıpçak, Sami Ayanoğlu, Ferdi Tayfur, Seyfi Havaeri and Hadi Hün) and a mixed group called the 'cinematographers'. The cinematographers were Faruk Kenç and Şadan Kamil, who studied film in Germany; Baha Gelenbevi, who worked in France as an assistant to Abel Gance; Turgut Demirağ, who studied film at the University of Southern California and worked for Leo McCarey and Cecil B. DeMille at Paramount; Vedat Örfi Bengi, who worked in France and Egypt; and, finally, Aydın Arakon, Çetin Karamanbey and Șakir Sirmali.

The years between 1940 and 1948 are described as the 'transition phase'. It began with a certain enthusiasm on the part of the film-makers, whose styles were by and 
large influenced first by Ertuğrul and then by Egyptian and Western films which were very popular in those years. Film production proceeded in a somewhat naïve manner, trying various genres and diverse methods of storytelling, and casting inexperienced actors and actresses. But this did not result in an avant-garde movement, independent from commercial interests. Film-makers made every attempt to attract an audience.

In 1948 the municipal tax on domestic films was reduced to 25 per cent, while the tax on foreign films remained at 70 per cent. The Turkish film business was now open to anyone who sought profit. Besides, film companies did not have to compete with US films anymore and they could risk money on adventurous projects. The beginning of this period is marked by the arrival of the cinematographers, who would finally shake off the deadening weight of Ertuğrul and his disciples.

This was still primarily a 'cinema of attraction'. Fight and chase scenes scarcely served the plot and posters show that the performances of belly dancers and orchestras were given special credit, promising entertainment. However, the cinematographers gradually learned how to tell a story coherently. Particularly, Lütfi Ömer Akad, Orhan Arburnu, Metin Erksan, Atıf Y1lmaz and later Memduh Ün developed new forms of expression and achieved a degree of unity in narrative structure.

\section{The contemporary Turkish cinema}

\section{Yeșilçam}

The period from the mid-1960s to the mid-1970s is marked by a mode of production and film performance that is unique in the history of Turkish cinema. Continually increasing demand from the audience caused a rapid expansion of the film business. While the film directors were at pains to reconcile the rules of commercial success and personal style, film production increased enormously. In 1961 the number of films made was 116, twice the figure of previous year, while in 1972 it reached its peak with 298 films. Production companies on Yeșilçam Street in the Beyoğlu district of Istanbul (hence 'Yeșilçam', literally 'Green Pine', cinema) went to the regional film distributors and haggled over plots and stars. Having a clear idea of their audiences' taste, the distributors could demand revisions to plot and casting. For instance, to guarantee profit the distributor of the Adana region might require two fight scenes if Cüneyt Arkin was to be cast in the leading role.

Table 4 Distribution and exhibition in the early 1970 s

\begin{tabular}{lccl}
\hline Regions & Towns & Movie theatres & Admissions \\
\hline Adana & 21 & 463 & $37,335,472$ \\
Izmir & 12 & 646 & $51,427,031$ \\
Ankara & 6 & 216 & $29,474,552$ \\
Samsun & 16 & 238 & $20,420,363$ \\
Marmara & 9 & 343 & $27,288,164$ \\
Zonguldak & 2 & 82 & $13,149,007$ \\
Istanbul & 1 & 436 & $67,402,721$ \\
\hline
\end{tabular}

Source: Abisel 1994: 100. 
The film industry was not capable of catching up with the speed of production; there was no capital reserved for the cinema, no investment was made in studios or even technical equipment. From the 1940s dubbing was standard practice, saving money on actors and studio time. Screenplays were written in a rush - sometimes on the spot - just before shooting started. In order to avoid changing lighting and camera set-ups, every object in the studio was given the same amount of light and the shotreverse system was abandoned almost entirely. That led to a hybrid visual convention that found a compromise between the tradition of two-dimensional Turkish miniatures or shadowplay and the Western regime of perspective. Thus the image lacked the dialectics of figure-background and visual depth, due to flat lighting. In addition, when conversing the actors did not face each other, but rather the camera, thus making full identification impossible for the spectator.

\section{Genres of Yeșilçam}

Yeșilçam, by deploying the powers of genre and stardom, set a horizon of expectations for its audience. This did not only guarantee commercial success, but also formed well-established conventions of storytelling. It must be noted, however, that in the mid-1980s these conventions collapsed with the emergence of the director as auteur. The auteur directors, instead of exploiting generic templates, primarily attempted to institute their own individual style.

Melodrama Melodrama is one of the most popular and powerful genres of Yeșilçam. In fact, the melodramatic mode runs across almost all genres. Yeșilçam's main audience was the family. Family melodramas play on a formula of disequilibriumequilibrium. In the beginning the family splits up due to some kind of misunderstanding or intrigue, but then reunites at the end thanks to the efforts of the children (Orhan Elmas, Adını Anmayacağım / I Shall Not Recall Your Name, 1971; Ülkü Erakalın, Afacan Küçük Serseri / Afacan, the Little Tramp, 1971; Metin Erksan, Feride, 1971). Other melodramas focus on heterosexual couples, underlining sociocultural conflicts on a number of axes: poor versus rich, rural versus urban, lower class versus bourgeois, Eastern versus Western. These conflicts are resolved in the realm of fantasy. In a typical plot, the downtown boy would seduce the poor girl from a village, the girl would then go to the city, disguised as a modern and rich woman, and take revenge (Metin Erksan, Dağdan Inme / Down from the Mountains, 1973; Orhan Aksoy, Kınalı Yapıncakı / Golden Red Grape, 1969).

Comedy Another popular genre of Yeșilçam was comedy, which was primarily based on gags and puns. Comedy can also use other genres (especially gangster films or science-fiction) to mock familiar elements. Many comedies were produced in series with the same cast playing characters-as-stereotypes. There are parallels between these films and situation comedy. However, Yeșilçam comedies bore melodramatic overtones at climactic points. Examples are the Hababam ... / Carry On ... series (six films between 1975 and 1981) by Ertem Eğilmez, starring Kartal Tibet, and the Turist Ömer / Ömer the Tourist series (seven films between 1964 and 1973), directed by Hulki Saner with Sadri Alıșik in the title role. Although comedy, like melodrama, reasserted values of family and home, it subtly produced points of resistance to power. In particular the 
Șaban series (eight films directed by the former star Kartal Tibet and partly inspired by the folk-hero Keloğlan) centres on a kind of village idiot (played by Kemal Sunal) undoing the conspiracy of a group of people in power who are aiming to abuse him. Finally it should be noted that parodies of US popular films and television series with a slight taste of trash (for example, Star Trek, Bewitched and The Pink Panther) made good box office, becoming Turist Ömer Uzay Yolunda / Ömer the Tourist on Star Trek, Tatlı Cadı / Sweet Bewitched and Pembe Panter / The Pink Panther.

Historical action / adventure Yeșilçam introduced a series of historical action heroes to the audience. Tarkan, Karaoğlan, Malkoçoğlu, Kara Murat and Battal Gazi are openly chauvinist superheroes, fighting in the name of their country or for some oppressed community against an enemy. Their actions are justified by the enemy's initial move (massacre, torture, breaking an oath and so on). These films produced sites of identification mainly for adolescents who assumed a national identity by imagining fights against the enemy.

Interestingly, these films often centre around a woman. When the hero is caught and put in the dungeon, the enemy's woman (having fallen for the hero) comes to his rescue, risking / sacrificing her own life. Cüneyt Arkın (who played Kara Murat, Malkoçoğlu and Battal Gazi) and Kartal Tibet (Karaoğlan and Tarkan) are the icons of historical action films. A strong appeal to heroism can be traced in other genres as well, but it can work in different ways. For instance, the 'tough guy' character (kabadayl) is a very common figure, whose distinguishing marks are still perpetuated today (particularly in television series). He comes from uptown and dutifully protects the poor and the weak from evil forces, demonstrating his power only when needed. His own interests (love for the girl-next-door or the opportunity to lead a decent life) are always subordinate to his concern for others (Yavuz Yalınkılıç, Cesur Kabadayı / The Brave Swasher, 1969; Y1lmaz Duru, Erkek Gibi Ölenler /Dying as a Man, 1970; Cevat Şahiner, Dört Kabadayı / Four Swashers, 1970; Kemal Kan, Istanbul Kabadayısı / The Swashes of Instanbul, Kara Murat / Dark Murat, 1972).

Detective / gangster movies Detective and gangster movies that were heavily influenced by US films initially appealed to audiences, but were eventually overtaken by a domestic version of Hong Kong karate films. In these films the family is only a pretext for revenge, and the chaste woman disappears in favour of the vamp in order to justify sexually suggestive scenes (Savaș Eșici, Șimșek Hafiye / The Bright Detective, 1970; Çetin İnanç, Zehir Hafiye / The Sharp Detective, 1971; Kaya Ererez, Çılgın Gangster I Crazy Gangster, 1973; Müjdat Saylav, O Bir Gangsterdi / He was a Gangster, 1973). The hero is usually a Mike Hammer lookalike who is always on the run, in sharp contrast with the committed male character of melodramas. While Y1lmaz Köksal was the exponent of these roles, Y1lmaz Güney also largely owes his fame to a melancholic variation on this type of character.

\section{New Turkish Cinema}

After the mid-1970s the family gradually vanished from movie theatres due to a combination of the socio-political catastrophe shedding blood in the streets and television now broadcasting entertainment to safe homes. Yeșilçam turned to a lumpen 
crowd and, in order to survive the economic crisis, started a career in pornography which would last until the military coup in 1980.

Regional distributors who provided money for production were replaced by video distributors who were willing to buy every film that a company stocked. Video distribution was primarily aimed at Turkish migrant workers living in Germany and other Western European countries. Thus, in order to exploit this new market abroad, film companies changed medium. They not only sold all of their films, but also began to produce films (mostly $16 \mathrm{~mm}$ ) and videos directly for the video market, which would soon include Turkey as well. Due to the drastic fall in the number of movie theatres during the late 1970s, lack of popular films, poor projection and the single state television channel which was still broadcasting in black and white, the early 1980s witnessed video shops mushrooming to the extent that hundreds of films never hit cinema screens. Video business soon began to function as a channel for piracy: in addition to Turkish features, US and even European videos were copied under dubious circumstances and circulated across the country until the government agreed to take action in the late 1980s over the copyright of foreign films.

The new liberal economy policy which was imposed after the 1980 coup gave way to an advertising boom, with significant consequences for feature production. Advertising companies established international connections and benefited from foreign expertise, both in management and in production. A number of Yeșilçam directors, as well as newcomers, were involved in the business, which promised more money than they could ever hope to make in Yeșilçam. At the same time they learned how to convey a message in a thirty-second commercial and how to devote utmost care to each frame. Working with foreign directors, art directors and directors of photography was valuable training for lighting and camera crews. This experience would eventually have an impact on feature-film production.

The directors of the post-1980 period were at pains to formulate their individual style of expression. For the first time in Turkish cinema, the marketing campaigns conceived and introduced the director as an auteur (although Metin Erksan is the first real auteur of Turkish cinema). Lighting, colour, editing and camerawork gave films a European look, different from the genre cinema of both Hollywood and Yeșilçam. Arguably one can observe the emergence of a New Turkish Cinema after the 1980s.

The cinema now formulated new problems and introduced new concepts. Two major trends emerged in the New Turkish Cinema. Films centred on women and attempted to study them in their own right or questioned the conventions of female representation. Women in the cinema were shown to express desires of their own, with the female protagonist struggling to solve her problems by herself. In Mine (At1f Y1lmaz, 1982), Mine (Türkan Șoray) begs the male character to sleep with her; in Dağınık Yatak / The Unmade Bed (Yılmaz, 1984), Benli Meryem (Müjde Ar), the mistress of a businessman, falls in love with a young waiter and takes him with her to a holiday resort; in Dul Bir Kadın / A Widow (Y1lmaz, 1985) and Bez Bebek / Rag Doll (Engin Ayça, 1987), a mature woman discovers her sexual desires. Kadının Adı Yok / Woman's Got No Name (Y1lmaz, 1987) is an adaptation of a best-selling feminist novel and tells the story of a woman (Hale Soygazi) in search of her identity, while the heroines (Füsun Demirel, Hande Ataizi, Sevtap Parman) of Mum Kokulu Kadinlar / Wax-scented Women (İran Tözüm, 1995) get rid of their oppressors (all played by the same actor, Halil Ergün) and start a new life. 
Another trend is a preoccupation with the possibilities of the medium itself. Selfreflexive films appeared, focusing on the production process, problems of representation, and the pleasures of voyeurism and exhibitionism. Adl Vasfiye / Vasfiye is Her Name (Y1lmaz, 1985) tells the story of men telling the story of Vasfiye (Müjde Ar), an enigmatic woman who refuses to speak about herself. Aaahh, Belinda! / Oh, Belinda! (Y1lmaz, 1986) is about an actress (Müjde Ar) who agrees to perform in a shampoo commercial and all of a sudden finds herself in the fictional world of the petit bourgeois screen family. In Hayallerim, Așkım ve Sen / My Dreams, My Love and You (Y1lmaz, 1987), the stereotypical characters played by a Yeșilçam star (who is ironically played by the Yeșilçam icon Türkan Șoray) plague a young man who is writing a screenplay for her. Gizli Duygular / Secret Feelings (Șerif Gören, 1984) plays on the notion of voyeurism, with allusions to Hitchcock's Rear Window; Film Bitti / The Film has Ended (Yavuz Özkan, 1989) is a film about making a film, and Arabesk (Ertem Eğilmez, 1988) is a pastiche of Yeșilçam melodramas. Gece Yolculuğu / Night Journey (Ömer Kavur, 1987), Üçüncü Göz / The Third Eye (Orhan Oğuz, 1988), Su Da Yanar / Water Also Burns (Ali Özgentürk, 1986) and Camdan Kalp / Heart of Glass (Fehmi Yașar, 1990) are all about the sufferings of a film director or scriptwriter, in search of himself or of some other kind of truth. Amerikal / The American (Gören, 1993) parodies the climactic scenes of US blockbusters (Home Alone, Basic Instinct, Pretty Woman and so on) and questions the ways in which they have been integrated into the Turkish imagination. Cazibe Hanımın Gündüz Düșleri / The Daydreams of Miss Attraction (İrfan Tözüm, 1992) shows a sexually voracious female character (Hale Soygazi) sitting in a rocking chair and restlessly watching images of Istanbul coming from a slide projector.

\section{The industry and audience today}

\section{Production}

Today, the main funding sources for film-makers are (1) producers (some of whom are US companies) who can risk money on indigenous films, (2) major firms that sponsor production entirely or partially, (3) the ministry of culture which provides loans, (4) television stations which support production on the condition that the broadcasting rights for the film be given to the station, and (5) 'Eurimages' which supports co-productions with partners from at least two other European countries. Not all of these sources are totally reliable: for example, the Ministry of Culture will not support every project and it may have to cut funding according to political decisions or to the budget allocated by the government.

\section{Censorship}

Censorship has been a matter for the police from the very beginnings of Turkish cinema and it defines one of the major ways in which the state has interfered with the industry. Although there was no law regulating the production, distribution, exhibition and import of films until 1932, the city governors of the Ministry of the Interior were felt to be fully authorized on the matter. In 1934 the Regulation on the Control of Films and Film Screenplays was formulated as part of the Police Duty and Authorization Law, and it was applied with minor revisions until 1977. The Board of Censors consisted of five main members (two from the Ministry of the Interior, one 
from the Ministry of Tourism, one from the Ministry of Education, one from the police). Depending on the content of the film, other members coming from the General Staff of the Army, the ministry of commerce and so on might join the Board, albeit on a temporary basis. The Board examined screenplays prior to the production of any film and had to announce the result of their deliberations within a certain time period (this also covered foreign films that were to be produced in Turkey). They might authorize a film, ban it or request revisions on the grounds that films should avoid (1) political propaganda about any state, (2) degrading an ethnic community or race, (3) 'hurting the feelings' [sic] of fellow states and nations, (4) propagating religion, (5) propagating political, economic and social ideologies that contradicted the national regime, (6) contradicting national and moral values, (7) denigrating the military forces and reducing their dignity and honour, (8) being harmful to the discipline and security of the country, (9) provoking crime, and (10) criticizing Turkey. The owner of a film and the representatives of ministries could also raise objections, which were addressed to the Ministry of the Interior, and ask for another meeting. The ministry would then forward the request to the Committee of Central Control, which was authorized to give a final decision. However, the Ministry of the Interior reserved the right to censor or ban a film, even if it had been approved by the Board of Censors. In 1977 the law was reformulated in such a way as to express concern for the mental health of juvenile audiences and loosely suggest a rating system be introduced.

Although great efforts were made to overthrow the tyranny of censorship, it remained virtually untouched until 1985. This prevented film-makers from promoting challenging ideas or developing any explicit social or political critique. In order to be able to produce and show their films, they took indirect routes. When they feared a film might be censored, they would submit a screenplay specifically prepared for the Board and produce their film based on a different screenplay, in the hope that the Board would not check the completed film against the previously submitted screenplay. The history of censorship is one of interference, interruptions and paranoid anecdotes. The year 1985 marked a return to a relatively democratic system which afforded 'freedom of speech' as a norm. In 1986 the Ministry of Culture became responsible for affairs of censorship, which brought about a considerable relaxation.

\section{Distribution and exhibition}

There were 2,242 movie theatres in 1970 (Abisel 1994) and, according to the results of research conducted by Nezih Coș, this figure soon reached 3,000 (Coș 1969). Most of these theatres exhibited Yeșilçam films, produced at an average rate of 200 films a year. By the mid-1970s the number of theatres began to drop rapidly. Many were converted into apartment buildings, business centres, carparks or small shopping centres. It was recorded that there were only 674 movie theatres left by 1986. In 1995, when the population of Turkey reached 60 million, the number of theatres had dropped further to 363 (half as many as in Greece, where the population was then only 10 million). Today a gradual increase is being observed, due both to rising demand from vast numbers of university students and to the popularity of the shopping centres with cineplexes that have been appearing in many big cities. However, $37.5 \%$ of all theatres still show foreign soft-porn films. Interestingly, these cinemas are concentrated in the most conservative regions of the country. Today there are at least 450 theatres, and this figure is likely to 
grow as international cinema chains (for example, Cineplex Odeon Corporation of Canada and Cinemax of Germany) expand in Turkey.

\section{Audience}

An increase in the number of cinemas does not, of course, necessarily mean that Turkish films reach the domestic audience. Film-makers repeatedly complain about the difficulty of booking theatres for their films. Even when they do manage to squeeze their own work in between films from the United States, their films are quite likely to crash at the box office and be withdrawn immediately - perhaps partly due to their failure to meet the expectations of a movie audience whose taste has, to a large extent, been shaped by Hollywood.

Table 5 Audience loss

\begin{tabular}{lcll}
\hline Year & Movie theatres & Admissions to domestic films & Admissions to foreign films \\
\hline 1959 & 285 & - & - \\
1970 & $2,242 / 3,000$ & - & - \\
1978 & 1,285 & - & - \\
1980 & 938 & - & - \\
1983 & 975 & $35,835,614$ & $45,133,962$ \\
1984 & 854 & $26,753,374$ & $29,562,237$ \\
1985 & 767 & $21,284,575$ & $21,386,030$ \\
1986 & 674 & $20,345,721$ & $19,857,030$ \\
1987 & 460 & $11,734,923$ & $13,097,248$ \\
1988 & 424 & $7,736,401$ & $12,553,466$ \\
1989 & 383 & $7,165,710$ & $13,882,149$ \\
1990 & 354 & $5,668,705$ & $13,565,271$ \\
1991 & 341 & $4,135,653$ & $12,408,040$ \\
1993 & 320 & & \\
1995 & 363 & $1,574,492$ & $7,825,302$ \\
1998 & 450 & data unavailable & data unavailable \\
\hline
\end{tabular}

Source: Data compiled from UNESCO Statistical Yearbooks 1963, 1973, 1981, 1983, 1987, 1993, 1998, Turkish Statistical Yearbooks 1990 and Türsak Yearbooks 1993, 1995/6, 1996/7, Variety (various issues).

Table 6 Fall in production

\begin{tabular}{lllc}
\hline Year & Turkish films in exhibition & Year & Turkish films in exhibition \\
\hline 1991 & 17 & 1996 & 9 \\
1992 & 10 & 1997 & 14 \\
1993 & 11 & 1998 & 10 \\
1994 & 16 & 1999 & 13 \\
1995 & 10 & 2000 & 15 \\
\hline
\end{tabular}

Source: Data compiled from A. Özgüç, Turk Filmleri Sölüḡü 1991-1996, and TÜRSAK Sinema Yıllı $\bar{g} l$ 1997-1998

Note: There may be a significant difference between production and exhibition figures. In 1993, for example, only eleven films out of eighty-two could be screened. 
After the mid-1980s the audience (now largely from a younger generation) returned to the cinema to see not indigenous films but Hollywood blockbusters. Discussions about applying quotas to imported films faded when President Bush invited Turgut Özal, then Turkish prime minister, to the White House and converted him to the virtues of a liberal trade policy. In order to bring in foreign money, the 'off-shore media project' launched in 1988 by the liberal government allowed US film distribution and exhibition companies to operate in Turkey. Almost all the movie theatres in the country were booked up by foreign companies, particularly the 'majors' (Warner Bros and UIP); they also began to control the video market, which was already declining because of the increasing number of state and private television channels. A positive result of this cultural invasion, however, was that theatres were renovated in order to catch up with 'global' standards of film viewing: comfortable chairs, air conditioning, digital Dolby-stereo sound systems and highquality projection equipment were all installed.

According to statistical data provided by Fida Film, which in 1997 ran a survey of 2,438 viewers from ten leading cities, there is a more or less even balance between male and female film-goers $(51.11 \%$ and $48.89 \%$ respectively). Generally, audience-members are young (between 19 and 35$)$, single (77.2\%) and either university graduates $(41.18 \%)$ or have completed their secondary schooling (40.44\%) (TÜRSAK 1997). Looking at the top grossing films of 1995-8, however, it is clear that children's films (Pocahontas, The Lion King, Richie Rich, Casper, 101 Dalmatians and Free Willie 2) are always at the top of the lists, and children are always accompanied by adults when they go to the cinema. Thus children form a most reliable segment of the audience. Another significant result of this research is that housewives are the least likely to go to a film $(10.30 \%)$. In part this might be due to the neglect of female audiences by both Hollywood and the New Turkish Cinema. What seems to be far more important in keeping the Turkish housewife at home, however, is television. There are more than fifteen national channels in Turkey, broadcasting old Yeșilçam films and 'female-friendly' soap operas during the daytime, and the frequency of commercial breaks suggests that they receive very high ratings. The situation is reminiscent of the 1970 s, when film exhibitors arranged daytime 'women only' screenings. Although Yeșilçam cinema did not achieve full product diversification, it was nevertheless able to address a diversity of audiences, with melodramas for single women and parents, adventure / action films for teenagers, kids films with child stars for children and parents, and comedy for just about everyone. Even now children, housewives and elderly people have yet to receive careful consideration as potential viewers in the marketing audience profiles.

This situation provoked the claim that Turkish films should bring the audience back to the cinemas. In recent years some productions have proved that a film can be both sophisticated and popular. The box-office successes of Yavuz Turgul's Muhsin Bey / Mr Muhsin (1986) and Eșkiya / The Bandit (1996); Ertem Eğilmez's Arabesk (1988); Sinan Çetin's Berlin in Berlin (1993) and Propaganda (1999); Șerif Gören's Amerikalı / The American (1993); Mustafa Altıklar's İstanbul Kanatlarımın Altında / Istanbul Beneath, Down Under My Wings (1995) and Ağır Roman / Cholera Street (1997); and Ömer Vargı's Herşey Çok Güzel Olacak / Everything Will Be Fine (1999), along with the long-expected re-release of Yilmaz Güney's Yol / The Way (1981), arouse the hope that other films may follow in the near future. John Nadler of Variety observed in May 1998: 
After being virtually eclipsed by free TV and US theatrical releases for most of the decade, Turkish film is resurrecting itself, and the country's producers, distributors and exhibitors have exhibited a new-found respect for domestically made movies.

(Nadler 1998: 61)

\section{Turkish cinema: transnational perspectives}

As mentioned already, the percentage of Turkish films shown in Turkish cinemas is relatively small in comparison to imports from Hollywood. Reception of films has always been international to varying degrees. Turkish cinema has developed a transnational presence for itself, as well as through the Turkish diaspora to Germany (where the resident population includes over 2 million people of Turkish origin) and other Western European countries. This expatriate population has formed a non-domestic market, particularly for the consumption of videos (and, more recently, satellite television) but also in terms of film production (by opening avenues to secure funding outside Turkey).

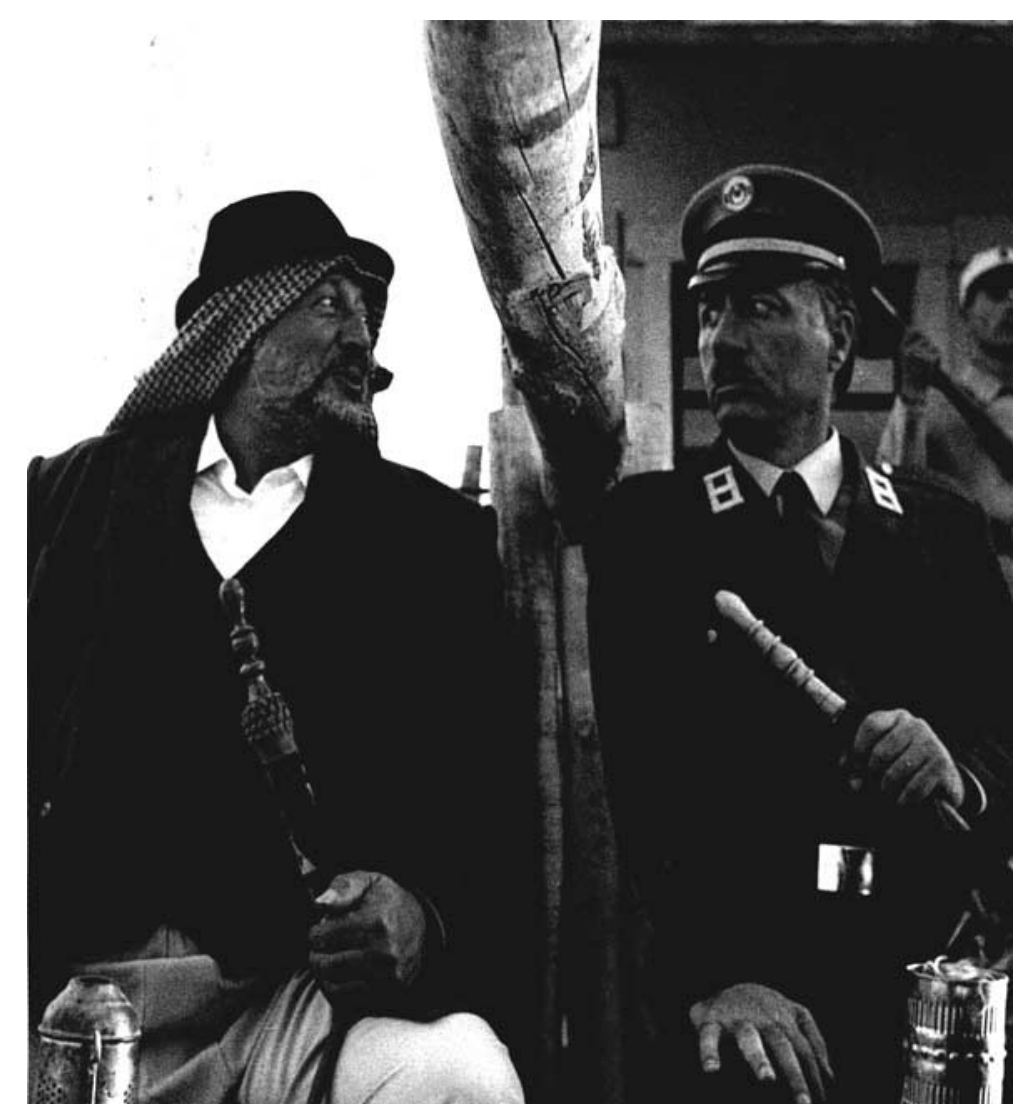

Figure 50 Metin Akpınar (left) and Kemal Sunal (right). Two veteran comedians of Turkish theatre and cinema meet in Propaganda. 


\section{Migration and cinema}

From the early 1960s, migration did not only lead from Turkey to Western Europe, but occured primarily within the country itself, from poor rural areas to the big cities. The population of Istanbul, for example, has grown from 2.5 million to approximately 16 million over the last thirty-five years. Considering the extent of social change brought about by this massive displacement of population, it is not surprising that migration has been an important theme in Turkish cinema. Melodramas or comedies often feature characters who have moved to the city and find it difficult to adjust to being there. Halit Refiğ in Gurbet Kușları / Birds of Exile (1964) or Ömer Lütfi Akad in his trilogy Gelin / The Bride (1973), Düğün / The Wedding (1973), Diyet / Blood Money (1974) explored the experience of migrants. More recently, films like Yol / The Way (1981) or Güneșe Yolculuk / Journey to the Sun (1999) have focused on mobility and rootlessness as common experiences of people in Turkey. Oğuz Makal (1994) lists further examples in his book about the 'seventh man' in cinema, a study that covers migration both within Turkey and abroad.

Following the labour migration from Turkey to Western Europe, primarily to Germany, film-makers have started making 'expatriate' films, set in the diaspora and partly produced and distributed outside Turkey. Tunç Okan's Otobüs / The Bus (1976) features the strange encounters of a group of migrant workers on the road to Sweden, depicting them as speechless victims, much in the style of John Berger and Jean Mohr's text and photograph book A Seventh Man (1975). A focus on alienation and incompatibility was to become the prevalent mode in depictions of migrants in the years to follow. The representation of Turkish women in the diaspora, in particular, centred around fantasies of subordination, confinement in claustrophobic spaces, rescue and liberation. In Germany, a kind of ghetto culture emerged that fed on wellmeaning discourses of integration and on a system of public funding. German film-makers, such as feminist director Helma Sanders (Shirins Hochzeit / Shirin's Wedding, 1975) or Hark Bohm (Yasemin, 1988), engaged in this victimizing depiction, as well as Turkish film-makers working within German structures of subsidy. Tevfik Bașer, for example, moved from Eskișehir to Hamburg, where he could realize his films with regional film funding. In his 40 QM Deutschland / 40 Squaremeters of Germany (1986), Turna (Özay Fecht) is brought to a flat in Hamburg and kept confined there by her husband for months. This film was nominated for a German national film prize (the Bundesfilmpreis). In Abschied vom Falschen Paradies / Farewell to a False Paradise (1988), Elif (Zuhal Olcay) ends up in a German prison for having killed her oppressive husband, but paradoxically her experience of imprisonment turns into an experience of liberation and integration. The spatial closure is conveyed through the mise-en-scène and framing. Characters are depicted in open spaces only in their subjective visions, mostly nostalgic memories of their home villages.

Only a few films - mostly produced in Turkey - transcended the prevalent rhetoric of social work in a more satirical and playful manner. Șerif Gören, who had focused on the problems of Turkish migrants in Almanya Acr Vatan / Germany, Bitter Home (1979), proceeded to make Polizei / Police (1988), a comedy starring Kemal Sunal as a streetcleaner who adopts the role of a German policeman in an amateur theatre performance, but becomes so fond of the uniform that he continues to wear it on the street, going around Turkish shops to ask for baksheesh. Mercedes Mon Amour (1992) is a black comedy about a Gastarbeiter ('guest worker'), in love with his yellow 
Mercedes, and his hazardous journey back home. The film is based on a novel by Adalet Ağaoğlu and directed by Tunç Okan and contains some moments of humour. Sinan Çetin's Berlin in Berlin (1993) has so far probably been the most adventurous exploration of intercultural encounters.

\section{'Europuddings' with Turkish ingredients}

The Council of Europe's film-funding scheme Eurimages was established at the end of 1988. The condition for funding any feature film is that independent producers from at least three different member-states participate in the project. The funding programme also offers assistance for distribution. Since the early 1990s about thirty-six Turkish co-productions have been funded by Eurimages, including Mavi Sürgün / The Blue Exile (Erden Kıral, 1993), Istanbul Kanatlartmin Altında / Istanbul, Beneath My Wings (Mustafa Altıklar, 1995), A ğır Roman / Cholera Street (Mustafa Altıklar, 1998), Ustam Beni Öldürsene / Sawdust Tales (Barıș Pirhasan, 1998), Eșkiya / The Bandit (Yavuz Turgul, 1996), Hamam / The Turkish Bath (Ferzan Özpetek, 1997), Güneșe Yolculuk / Journey to the Sun (Yeșim Ustaoğlu, 1999). European funding initiatives like Eurimages are part of a cultural policy scheme that was designed to reinvent Europe. Turkey, which is not yet a full member of the European Union, is nevertheless included in efforts to create a European cinema. An inclusive European space can best be imagined through travel, and consequently quite a few so-called 'Europuddings' have been about journeys. Mavi Sürgün is about a journey of exile within 1920s Turkey, from the capital to a remote village on the Aegean coast; Istanbul Kanatlartmin Altında about learning to fly in sixteenth-century Istanbul; Ustam Beni Öldürsene about the desires and destinies of circus acrobats; Eșkiya about a bandit of the old school who feels displaced in the modern metropolis; Hamam about a busy Italian who travels to Istanbul because he has inherited an old building from a deceased aunt, and gets increasingly entangled in this foreign place; Güneșe Yolculuk about uprooted Turkish and Kurdish characters and a journey to a home which no longer exists. Overall, European funding seems to have contributed to opening up broader horizons and paving the way for a Turkish cinema that travels - possibly beyond Turkey.

\section{New German Cinema - made by young Turks}

Recently there have been some new departures in diaspora film production. A new generation of Turkish-German film-makers and actors is emerging, mostly based in Hamburg or Berlin. Kurz und Schmerzlos / Short Sharp Shock, a fast-paced thriller which was the debut of Hamburg-based director Fatih Akın and nominated for the German Film Prize, was shown in London in December 1998 at the German Film Festival in the West End, as well as the Turkish Film Festival at the Rio Cinema in Dalston, both within the same week - an interesting overlap which points to the transnational potential of films like this. Aprilkinder / April Children (1998), directed by Yüksel Yavuz, is a trilingual melodrama that depicts a Kurdish immigrant family and their somewhat wayward offspring. Meanwhile the discourse of victimization of Turkish girls 'between two cultures' still persists. Yara / The Wound (1998), a German-Turkish-Swiss co-production (with Eurimages funding) by director Y1lmaz Arslan, is the story of a fragile young girl who is taken back to Turkey against her will 
to stay with some relatives, runs away and winds up in a psychiatric clinic, disorientated and distraught. Ich Chef, Du Turnschuh / Me Boss, You Sneaker (1998), directed by Hussi Kutlucan (who also plays the main part), is one of the few comedies in this area, notable for scenes that foreground masquerade and the performance of ethnicity. The adventures of the asylum-seeker Dudie take us from a refugee-camp in Hamburg to a building site right in the centre of Berlin.

At the Berlin Film Festival in February 1999, when debates about double citizenship were at their peak, many of these films were shown as 'New German Films' and two brand-new productions were presented with great critical acclaim: Thomas Arslan's new film Dealer, which offers a rather unglamourous, minimalist vision of Berlin, staging the main character against the background of housing estates, green parks or pointilistic traffic lights; and Kutluğ Ataman's Lola und Billidikid, which opened the Panorama section of the festival, is a flamboyant family melodrama and thriller set in the gay and transvestite scene of Berlin. The world distribution of this film is handled by Good Machine International, the same company that distributed Ang Lee's The Wedding Banquet - another signal perhaps that Turkish-German film is venturing into the realm of transnational cinema.

\section{Reception of Turkish cinema abroad}

'Expatriate' films for and about the diaspora population, European funding and coproductions have challenged the definition of Turkish cinema in simply national terms. Meanwhile, Turkish films have become a more noticeable presence at international festivals. Since 1993 the Turkish Film Festival in London has been presenting a good selection of films (both indigenous and expatriate productions). Over the past couple of years a few films (Eșkiya and Hamam) have gained wider distribution in Europe. At the Berlin Film Festival in 1999 Güneșe Yolculuk and other films by young Turks received critical acclaim and awards. For a long time the only cinematic images of Turkey retained in the cultural memory were based on Midnight Express (Alan Parker, 1978) and Yol - images of imprisonment, cruelty and oppression. Today there seems to be hope that Turkish cinema is becoming more multi-faceted.

\section{Filmography}

Adı Vasfiye / Vasfiye is Her Name

1985, 90 mins, colour, Turkish

Director: Atıf Yilmaz

Producer: $\quad$ Estet Video (Cengiz Ergun)

Screenwriter: Barış Pirhasan

Cinematographer: Orhan Oğuz

Music:

Art Director: Atilla Özdemiroğlu

Leading Players:

Șahin Kaygun

Müjde Ar, Aytaç Arman, Yılmaz Zafer, Macit Koper, Erol

Durak, Suna Tanrıverdi, Oktay Kutluğ, Ali Rıza Tanrıverdi

A young writer goes in search of a woman and meets the men in her life. Each tells the 
writer their own part of her story, until the man realizes that they are actually their stories and not hers. He finally succeeds in locating her in a nightclub. He begs her to tell him the truth about herself, but Vasfiye keeps silent. At the end of the film he understands that his encounter with her was not real, although he is still carrying the flower she gave to him. The stories told by the male characters are parodies of various genres of Yeșilçam: children falling in love, a young man beating up the men who damaged his honour, a man kidnapping his beloved, a paramedic making love to the women who called for him to give her an injection, a young doctor falling for the plain small-town girl - all male fantasies, repeatedly reproduced and presented by Yeșilçam. The film catches the audience red-handed: it first promises fantasy and then shows its impossibility - in the end, the frame freezes and breaks into pieces like a shattering mirror, which reminds the audience that what they have been watching was their own projection. Adl Vasfiye announced the death of Yeșilçam and its audience. Ironically, the release of this film coincided with Turkish cinema losing its audience.

\section{Berlin in Berlin}

1993, 117 mins, colour, Turkish

Director:

Producer:

Screenwriter:

Cinematographer:

Music:

Art Director:

Leading Players:
Sinan Çetin

Plato Film Production

Sinan Çetin, Ümit Ünal

Rebekka Haas

Nezih Ünen

Zeynep Tercan

Hülya Avșar, Cem Özer, Armin Block, Aliye Rona, Eșref Kolçak

A genre mix that incorporates elements of the thriller, melodrama and comedy, this film offers a rather bizarre vision of cross-cultural encounters, set in the reunified Berlin. The camera playfully engages in an investigation of voyeurism and dissects the power of the ethnographic gaze. The story begins on a building site. Thomas (Armin Block), a German engineer and amateur photographer, follows the wife (Hülya Avșar) of a Turkish colleague with his camera and takes photos of her without her noticing. When her husband sees the photos he is infuriated, assuming that she has deliberately posed for the camera and exposed herself to the gaze of a stranger - an offence against his honour. In the resulting row the husband is pushed against an iron bar and thus killed by accident. Thomas's attempts to apologize lead him into the home of the husband's family in Kreuzberg. His discovery gives rise to turmoil. Mürtüz, the angry young man (played by popular talk show star Cem Özer), claims that the stranger has murdered his brother and threatens to kill him with his pistol. The chase is stopped, just in time, by the father and the grandmother (Aliye Rona) who pronounce that Thomas is a guest, 'sent to them by God' as a 'trial', and therefore cannot be harmed while inside their home. Thus Thomas is given asylum in the Turkish family home - a reversal of the situation of foreigners seeking asylum on German territory. He settles on the floor for a life in 'Berlin in Berlin' or '4 squaremetres of Germany' and is gradually incorporated into family life. When relatives come to visit, Thomas is the chief attraction. It is now the Turks who are watching the German, almost like a circus 
animal, and who stare at him in claustrophobic close-ups. Described as a 'multicultural melodrama' in Germany, Berlin in Berlin was a box-office hit in Turkey, predominantly because it featured Hülya Avșar, an actress and singer popular on Turkish television, in a masturbation scene.

\section{Canlı Hedef / Live Target (a.k.a. Kızım İçin / For My Daughter)}

1970, 88 mins, colour, Turkish

Director / Screenwriter: Y1lmaz Güney

Producer: $\quad$ İrfan Film (İrfan Atasoy)

Cinematographer: Ali Yaver

Leading Players: $\quad$ Yılmaz Güney, Hülya Darcan, Yıldırım Gencer, Bilal İnci, Danyal Topatan, Erdo Vatan, Peri-Han, Melek Görgün

Asım Mavzer (Y1lmaz Güney), an ex-gangster, returns from Europe. An army of enemies is waiting for him to seek vengeance for various affronts. Bilal (Bilal İnci) sends his man Jilet (Gillette: razor) to see if Asım's old friends know his whereabouts. Jilet leaves a scar on the face of everyone he visits, but finds out nothing. Asim's best friends, Aspirin (Danyal Topatan) and Korsan (Y1ldırım Gencer), two social dropouts, scare Jilet away and then run into Cino (Erdo Vatan), a classy enemy of Asim who is determined to duel with him. Bilal kidnaps Asım's daughter and one of his men rapes her before his eyes. Asım breaks his word and begins to take revenge. In the ensuing shoot-out, Cino joins Asim and they together demolish the gang. Aspirin and Cino die. Asim and Korsan surrender to the police.

Güney made Canlı Hedef the year he produced Umut / Hope, a much admired film shot in a style reminiscent of Italian neo-realism. Savaş Arslan has argued that film critics and historians favoured Güney's Umut and other art films at the expense of his more entertaining action / adventure movies. It was these films, however, that made Güney popular with the masses, and cinematically they are equally well-crafted as those that brought him international recognition. Asim wears an extravagant outfit for the shoot-out: black shirt and trousers, red scarf and a black hat with a red band around it. Aspirin explains how he got his epithet: "whenever a woman had a headache, toothache, whatever, she seeks me out first, because the moment I kiss her the pain disappears just like that.' He often asks his comrades to listen to his dirty stories, but they always hush him. In the finale, when he is mortally wounded, he wants to tell his story again. This time Korsan says he wants to hear it. Aspirin begins but cannot continue. So, in a sense, the film ends with an untold story.

\section{Eșkiya / The Bandit}

1996, 121 mins, colour, Turkish

Director:

Yavuz Turgul

Producer:

Filma-Cass (Mine Vargi), Artcam, Geopoly

Cinematographer:

Uğur içbak

Editor:

Music:

Onur Tan, Selahattin Turgut

Art Director:

Erkan Oğur

Mustafa Ziya Ülkenciler 
Leading Players:

Șener Șen, Uğur Yücel, Kamuran Usluer, Necdet Mahfi Ayral, Kayhan Yıldızoğlu, Șermin Șen Hürmeriç

Baran (Șener Șen) is a bandit who was in prison for over thirty years. After his release he goes to his village, only to see that it is now flooded because a new dam has been built. He meets the old woman of the village who has not moved out. She gives him an amulet, implying that his ordeal is not over. Baran finds out that it was his friend, Berfo (Kamuran Usluer), who turned him in, in order to marry Baran's fiancée, Keje (Șermin Șen Hürmeriç). Baran takes a train to Istanbul where Berfo, now called Mahmut Șahoğlu, lives as a powerful businessman. On the train he makes friends with Cumalı (Uğur Yücel), a young drug dealer who is dreaming of making his way to the top. After they arrive in Istanbul Cumalı helps Baran and a father-son relationship starts to develop. Baran finds Keje, who has refused to speak since she married Berfo. They decide to leave Istanbul together, but Baran learns that Cumalı is in trouble, so he and Keje make a deal with Berfo: Keje will stay with him on condition that Berfo provides the money that will save Cumalı. But Berfo cheats them and eventually Cumalı gets killed by his own boss, Demircan. Baran takes revenge, killing Demircan and his men, and then Berfo. He hides on the roofs of Istanbul, just as he hid in the mountains thirty years earlier, but cannot escape death.

Some of the themes and issues raised by this film are (1) socio-cultural and even topographical change (Baran cannot cope with the changing morals of the big city; Baran's village is now underwater); (2) love for its own sake (Berfo loves Keje more than anything - his love transcends the codes of law, friendship, loyalty, faith and so on - but he gives up Keje in return for Cumalı's life); and (3) family reunion (Cumalı finds his long-dead father in Baran and Baran sees Cumalı as his unborn son). The film can also be read as a metaphor for Turkish cinema's attempt to survive: being the most expensive production ever, Eșkiya is a post-Yeșilçam film that challenges and mocks Hollywood. The cinematography, soundtrack, special effects and editing display a technical perfection that was compared by critics and audiences to that of Hollywood. There are some moments when the film parodies scenes from US films: Cumalı kills his treacherous girlfriend in a style reminiscient of Tarantino; the rooftop encounter between Baran and the rising police helicopter is a recurrent scene in US action films.

\section{Gelin / The Bride}

1973, 97 mins, colour, Turkish

Director / Screenwriter: Lütfi Ömer Akad

Producer: Erman Film (Hürrem Erman)

Cinematographer: Gani Turanl

Music: Yalçın Tura

Leading Players: $\quad$ Hülya Koçyiğit, Kerem Yılmazer, Ali Șen, Kamuran Usluer, Kahraman Kıral, Aliye Rona

Gelin is about internal migration from rural areas or provinces to the big city. Veli, his wife Meryem and their son arrive in Istanbul to join his parents and elder brother, Hidir, who are working hard to make a fortune in the 'big city which is made of solid 
gold'. They are so carried away with their dreams that they cannot see that the little boy, who is in poor health, is dying. The film is important as it is succeeds in presenting the conflicts arising from migration without lapsing into melodrama. It subtly depicts the crisis in the values of the extended family that was brought about by industrialization. They look in disgust at their neighbour who lets his wife work in a factory and refuse to pay for the recommended operation for the ill child. Interestingly, however, it is the woman (Meryem) who acts as an agent of modernization. Against the will of her family, she takes her son to the doctor, demands money for medical treatment and, when the child dies, burns down the shop and leaves home to work in a factory. In the finale, the husband, who has been ordered to kill Meryem for the dishonour she brought to the family, finds her and asks if there is a job for him, implying that he wants a reunion (hence the emergence of the nuclear family in industrial society).

Güneșe Yolculuk / Journey to the Sun

1999, 104 mins, colour, Turkish / German / Dutch

Director / Screenwriter: Yeșim Ustaoğlu

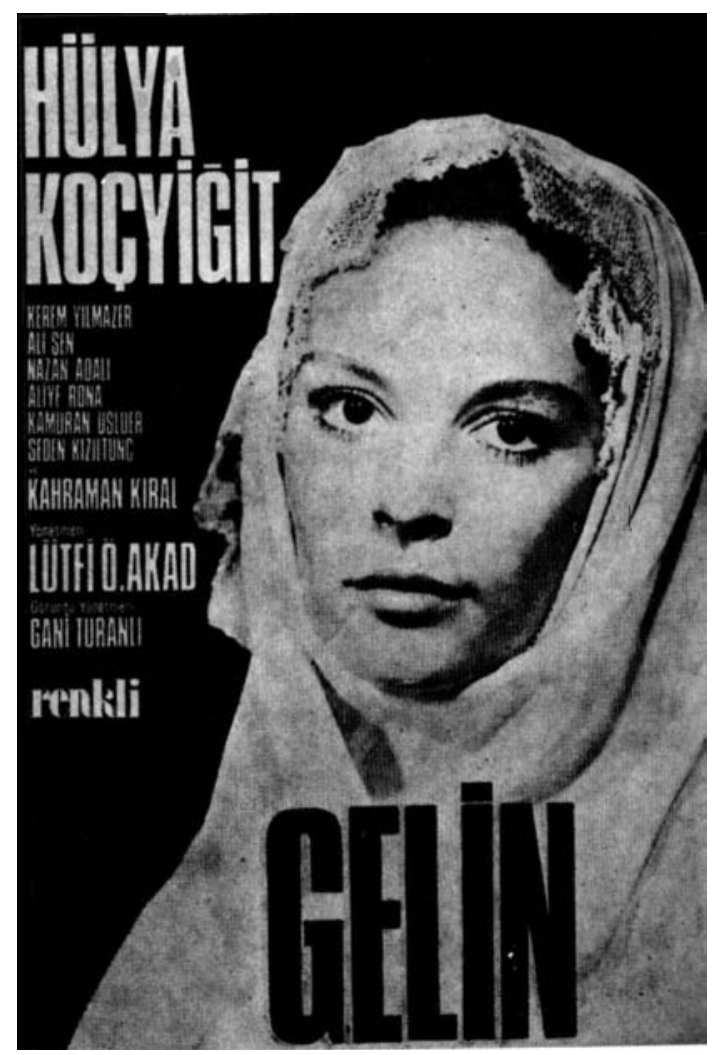

Figure 51 Gelin/ The Bride 
Producer:

Cinematographer:

Music:

Leading Players:
Ifr (Behrooz Hashemian), The Filmcompany Amsterdam, Medias Res Berlin, Fabrica, Arte / ZDF

Jacek Petrycki

Vlato Stefanovski

Newroz Baz, Nazmi Qirix, Mizgin Kapazan, Nigar Aktar, İskender Bağcılar, Ara Güler

Güneșe Yolculuk is an accomplished production, which received funding from Eurimages and television channels Arte and ZDF. The film is a courageous exploration of ethnic segregation and its fatal, often absurd, consequences. It is also the first Turkish film since Y1lmaz Güney's Yol to engage explicitly with Kurdish issues. The story of a friendship between two young men, a Turk (with 'Kurdish' looks) and a Kurd, is powerfully performed by amateur actors Newroz Baz and Nazmi Qirix. The story begins in the milieu of poor migrants living on the fringes of Istanbul. After the death of the Kurd at a public protest, his friend sets out on a journey through Turkey to take his coffin back home to the Kurd's village - only to find that his home no longer exists. The village has been demolished and deserted. Beautifully photographed, the film shows a refined sense of space and architecture. At the Berlin Film Festival in February 1999 it was awarded the Peace Prize and the Blue Angel Prize.

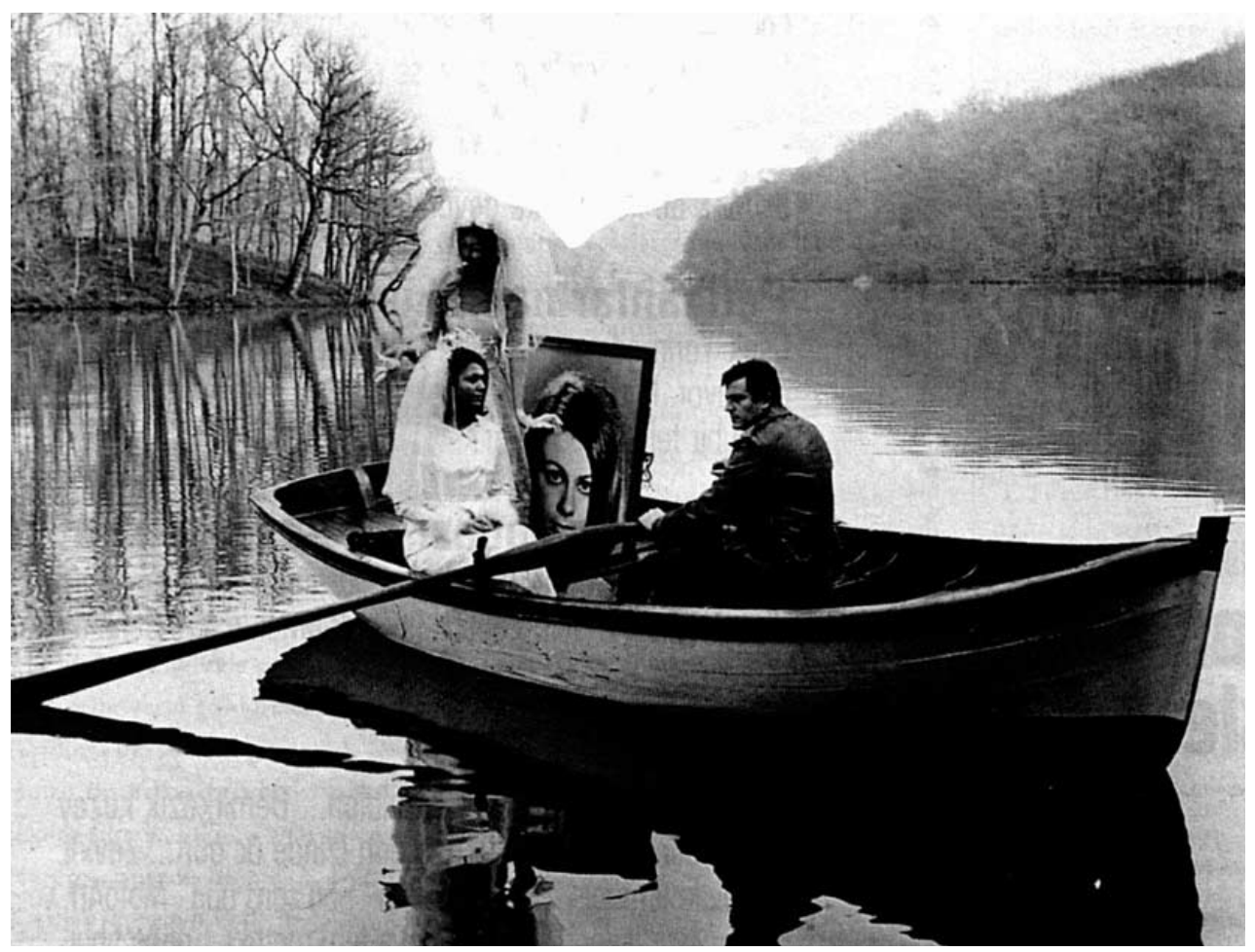

Figure 52 Sevmek Zamanı / Time of Love, an exploration of love and the problem of representation. 


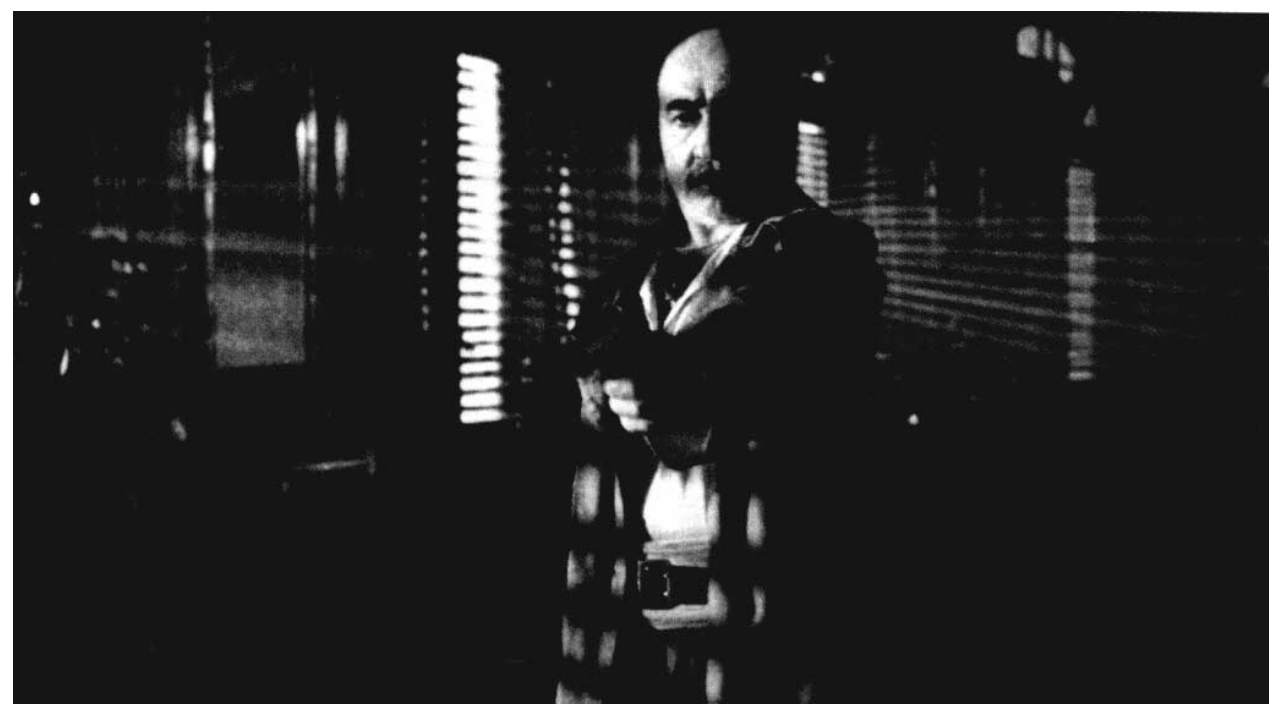

Figure 53 The bandit of the mountains goes to the city. Şener Şen in Eşkiya / The Bandit.

Sevmek Zamanı / Time to Love

1965, 90 mins, black and white, Turkish

Director / Screenwriter: Metin Erksan

Producer:

Troya Film (Metin Erksan)

Cinematographer:

Mengü Yeğin

Music:

Metin Bukey

Leading Players:

Müșfik Kenter, Sema Özcan, Süleyman Pekcan, Fadil Garan, Adnan Uygur

Sevmek Zamanı is a film more talked about than seen. A house painter falls in love with the enlarged photograph of a girl, but refuses to love the girl herself. The film is considered to be an allegorical study of the image / referent distinction, a very commonly used concept in the esoteric teaching of Sufism. The hero cannot transcend the illusion that the photograph offers and acquire the truth to which it refers. However, the film is open to alternative readings, one of which could be psychoanalytic. What is common to almost all of Erksan's films are fetish objects and men obsessively enjoying these objects. Sevmek Zamanı runs along the same lines, and calls for an examination of the psychological structuration of Erksan's filmic discourse.

\section{Sürtük / Streetwalker}

1965, 94 mins, black and white, Turkish

Director:

Producer:

Screenwriter:
Ertem Eğilmez

Arzu Film

Sadık Șendil 
Cinematographer:

Music:

Leading Players:
Cahit Engin

Metin Bukey

Türkan Șoray, Cüneyt Arkın, Ekrem Bora

Ekrem (Ekrem Bora), a tough, self-made man and the owner of a music-hall chain, wagers with his girlfriend that he can make anyone a star. He happens to hear Türkan (Türkan Șoray) sing in an underrated place and picks her to win the bet. He hires a piano player (Cüneyt Arkın) to give her music lessons. Unaware of the fact that Ekrem is also determined to possess what he has created, Türkan falls in love with Cüneyt. They attempt to escape, but no one in the entertainment business dares to employ them. When Ekrem finally threatens Türkan with murdering Cüneyt, she agrees to leave him. They arrange a small scene to convince Cüneyt that Türkan never loved him. But Ekrem now understands how much she loved him, so he regrets what he did to them. The damage can be repaired: in the finale, Ekrem brings the lovers together in a music hall and then goes into the lonely streets. Playing on the theme of sacrifice, Sürtük presents a typical plot in melodrama: the woman not only wins her lover back when she agrees to sacrifice her body, but she is also able to reform the bad. In melodramas, love must transcend the body, but the sacrifice of the body puts everything back in order. Eğilmez filmed a remake in 1970.

Teyzem / My Auntie

1986, 102 mins, colour, Turkish

Director:

Halit Refiğ

Producer:

Burç Film (Fedai Öztürk)

Screenwriter:

Ümit Ünal

Cinematographer:

Ertunç Şenkay

Music:

Atilla Özdemiroğlu

Leading Players:

Müjde Ar, Yaşar Alptekin, Mehmet Akan, Tomris Oğuzalp, Necati Bilgiç, Serra Yılmaz

This post-coup film narrates the story of Uftade from her nephew's point of view. She is a member of a middle-class family that perfectly mirrors the paranoia of the political atmosphere of the 1980s. Uftade's boyfriend Erhan disappears when she expresses her desire to marry him. Her elder brother goes to Germany to work and later returns as a religious man. Her father has died and her mother has married an ex-army officer, a despotic man who begins to make sexual advances to Uftade. Her mother cannot do anything about it, because she has been paralyzed by a stroke. Uftade marries a young man who treats her badly to cover up his sexual impotence. He manages to have sex with her only when his mother has commanded him to do so. Having divorced her husband, Uftade returns home, only to go through a series of ordeals which finally drive her to madness. Finally, she sees Erhan in a dream. He is dressed in a sultan's costume and says: 'I will come in lights and take you away with me'. One night she rushes out into the street and sees him approaching in lights. It turns out to be a truck, which kills her. As Deniz Derman argues: 
Teyzem was produced in the 1980s after the military intervention and the mother stands for the silent people who are not allowed to speak, but must obey the stepfather's rules. The stepfather stands for the military government, the dead father stands for democracy and Uftade's voice for the rebel.

(Derman 1996: 109)

The film goes into the details of social life and strikingly reveals how fascism operates from within, as if to prove the point that 'the political is personal'.

\section{Yol / The Way}

1981, 111 mins, colour, Turkish

Director:

Șerif Gören

Producers:

Güney Film /Cactus Film

Screenwriter:

Y1lmaz Güney

Cinematographer:

Erdoğan Engin

Music:

Sebastian Argol, Kendal

Leading Players:

Tarık Akan, Șerif Sezer, Halil Ergün, Meral Orhonsay, Necmettin Çobanoğlu, Semra Uçar, Hikmet Çelik, Sevda Aktolga, Tuncay Akça, Hale Akınlı, Turgut Savaş, Hikmet Taşdemir, Engin Çelik, Osman Bardakçı, Enver Güney, Erdoğan Seren

Although this may be the only Turkish film known to an international audience, it was not released in Turkey until 1999. Yol received much acclaim, including the Palme d'Or at the Cannes Festival in 1982 (co-winner with Costa Gavras's Missing), but it remained banned in Turkey, primarily because of its explicit references to Kurdistan. Yol confronted the audience with harsh realities about their country. It presents five parallel stories, following the journeys of five prison-inmates who are released for ten days and travel back to their families, only to discover that life outside the prison is as harsh and oppressive as it is inside. The military presence after the 1980 coup is very noticeable throughout the country. Shootings are common along the south-eastern border where one of the men returns. There he rides his horse but must sacrifice his beloved because custom requires him to 'take over' his dead brother's wife. Generally, family relations come across as oppressive and cruel, especially with regard to women: one woman is frozen to death in snowy mountains, another is killed on a train by her brother for refusing to separate from her husband. Due to the strong performances of the actors and the epic scale of the cinematography, this film remains very powerful.

\section{List of directors}

Akad, Lütfi Ömer (b. 1916, Istanbul, Turkey)

Akad is the most prominent director of the cinematographers period. Originally a designer, he took up film-making in the 1940s and began a brilliant career that lasted until the mid-1970s. His films reveal a departure from the theatrical style (he asked his actors not to perform as if on stage) and the search for a individual cinematographic 


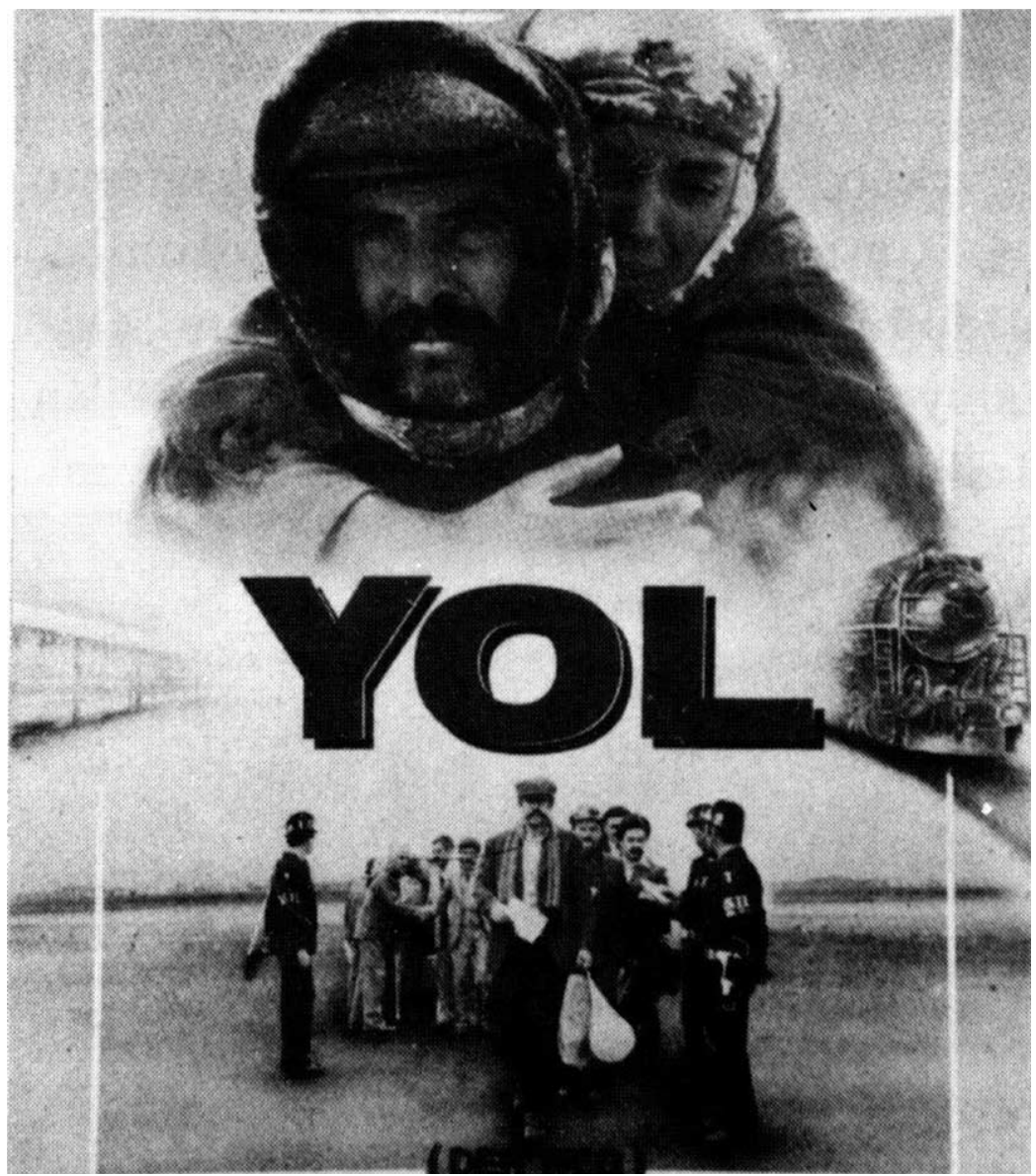

Figure 54 Yol/ The Way

style. The audience warmly welcomed his first film, Vurun Kahpeye / Strike the Whore (1949), which was an instant blockbuster. He later made policiers (detective films) under the influence of US films, usually depicting the male hero as a wounded man on the run, who is drawn into crime due to his innocence or to social conditions. Akad successfully stages the action against the cityscape of Istanbul, showing the hero's inevitable destruction in the end (Kanun Namina / In the Name of the Law, 1952; Öldüren Șehir / Murderous City, 1954; Katil / The Murderer, 1953; Ü̧ Tekerlekli Bisiklet / Tricycle, 1962). He mastered his style in his first trilogy: Hudutlartn Kanunu / The Law of the Borders (1967), Ana / Mother (1967) and Kizilirmak Karakoyun / Red River Black Sheep (1967), this time far removed from urban territory. His second trilogy is a study in migration from rural areas to the big city. Gelin / The Bride (1973), Dügün / The Wedding (1973) and Diyet / Blood Money (1974) explore the family at the centre of the cultural conflicts and disintegrating forces of the city, interweaving social and human themes in a delicate manner. Akad also tried his hand at documentaries 
and short television films. He retired from directing features in the mid-1970s and currently teaches film at the Mimar Sinan University in Istanbul.

\section{Çakmaklı, Yücel (b. 1937, Afyon, Turkey)}

Çakmaklı wrote film reviews before he began directing feature films (although his first film was a documentary on pilgrimage). His early films criticized Westernization, promoting religious and national values instead. Characters who lead a Western lifestyle find themselves in a cul-de-sac until they discover religion (Birleșen Yollar / Crossroads, 1970; Çile / The Passion, 1972; Oğlum Osman / Osman, My Son, 1973; Memleketim / My Homeland, 1974). After directing some very successful historical television serials, Çakmaklı returned to film-making, this time concentrating on the theme of the tortured Muslim. His films (Minyeli Abdullah / Abdullah from Minye, 1989; Minyeli Abdullah 2, 1990; Kanayan Yara Bosna / Bosnia, the Open Wound, 1994; Bosna, Mavi Karanlik / Bosnia, the Blue Darkness, 1994) were highly popular with large religious audiences at a time when commercial cinema was rapidly declining.

\section{Çetin, Sinan (b. 1953, Van, Turkey)}

Çetin started his career in painting, photography and graphic design. He entered the film world as an assistant director on Zeki Ökten's comedy Hanzo (1975) and went on to work with Şerif Gören and Atıf Yılmaz. Çetin graduated from the Art History Department at Hacettepe University in Ankara in 1977 and directed two documentaries within the same year: Baskin / The Raid and Hall Türküsü / Carpet Song. In 1980 he directed his first feature film, Bir Günün Hikayesi / Story of a Day. Other

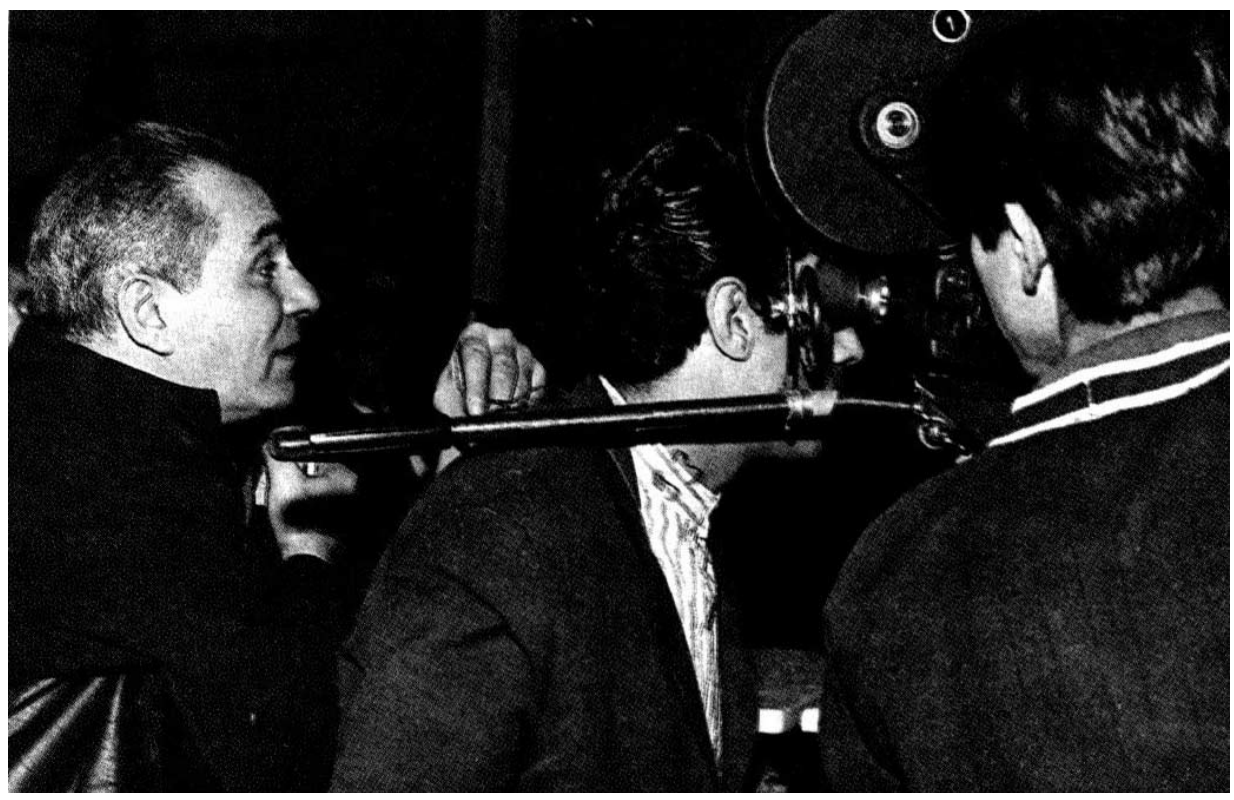

Figure 55 Lütfi Akad: In search of a cinematic language 
features followed: Çiçek Abbas / Abbas in Flower (1982), Çirkinler de Sever / Ugly but in Love (1982), 14 Numara / No. 14 (1984), Prenses, Gökyüzü / Princess, Heaven (1986). In the 1980s he also directed commercials for television which helped him to develop his cinematic style. The sophisticated cinematography and fast-moving pace of his more recent, commercially successful films Berlin in Berlin (1993) and Bay E/ Mr. E (1994) bear traces of this training in advertising. His latest film is Propaganda (1999).

\section{Eğilmez, Ertem (b. 1929, Istanbul, Turkey; d. 1989, Istanbul)}

Formerly a publisher of bestsellers and humorous magazines, Eğilmez began to make films in 1964. His Sürtük / Streetwalker (1965), an adaptation of Pygmalion, was an immediate blockbuster and he produced a remake in 1970. He followed Hollywood's narrative logic (he had a handbook on screenwriting translated into Turkish which he lived by) but nevertheless his films had an exclusively indigenous quality. They may be considered 'folk films' in the sense that he made films about the people who filled the cinemas. His melodramatic comedies particularly are vivid illustrations of the life of the lower middle class (characters showing solidarity against a contractor who offers the locals good money for their houses, women preparing the meal for a picnic in the countryside, local football players breaking the neighbour's glass windows, secret

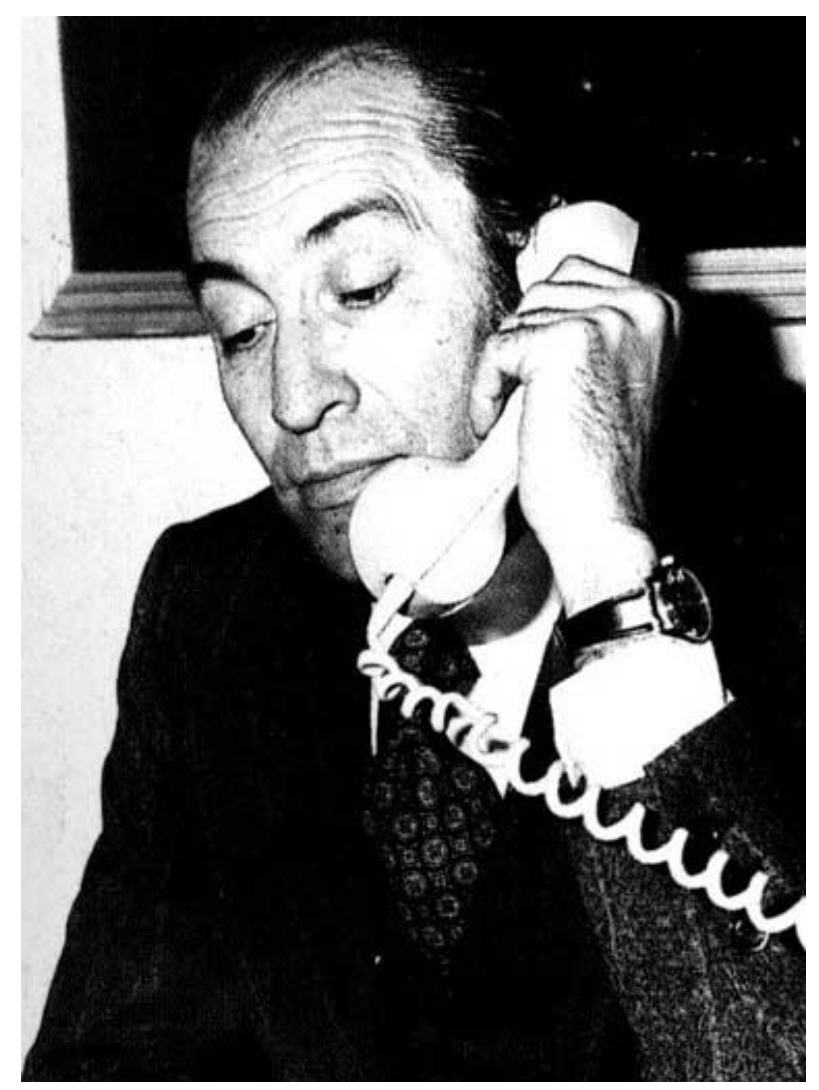

Figure 56 Ertem Eğilmez: movie mogul and film director 
lovers exchanging glances, harmless neurotics in funny situations, and so on). His Hababam ... I Carry On ... comedy series (Hababam Sinifi / The Carry On Students, 1975; Hababam Sinifi Sinifta Kaldı / The Carry On Students Fail, 1975; Hababam Sinifi Uyaniyor / The Carry On Students Wake Up, 1975; Hababam Sinifi Tatilde I The Carry On Students on Holiday, 1977; Hababam Sinifi Güle Güle / Farewell, Carry On, 1981) appealed to younger generations and presented the audience with some of the most successful stars of Turkish cinema (Tarık Akan, İlyas Salman, Șener Șen and Kemal Sunal) who are still working today. Interestingly, his last film before his death (Arabesk / Arabesque, 1988) is a comic pastiche of Yeșilçam melodramas, including his own most successful films.

\section{Erksan, Metin (b. 1929, Çanakkale, Turkey)}

Erksan attracted attention with social realist films set in a rural environment: Karanlik Dünya: Așık Veyselin Hayatı / The Dark World: The Life of Veysel the Poet (1952), Dokuz Dağın Efesi / The Swashbuckler of Nine Mountains (1958), Yllanların Öcü I The Revenge of Snakes (1962), Susuz Yaz / Dry Summer (1963) and Kuyu / The Well (1968). Susuz Yaz received the Golden Bear at the Berlin Film Festival in 1964. Erksan is the first auteur and star-director of Turkish cinema, and founded the Film Industry Workers' Union in 1962. His critique of the hegemony of the upper classes over the disposessed went hand in hand with a search for a personal style of expression. Unusual camera angles, geometrical compositions and the excessive use of fetish objects (such as big portraits dominating the filmic space) are characteristic of his less commercial works like Suçlular Aramızda / Criminals Among Us (1964) and Sevmek Zamanı / Time to Love (1965). In Intikam Meleği / Angel of Revenge (1976), Hamlet (who is played by female star Fatma Girik) listens to classical Turkish music records on a bed outdoors. Sensiz Yașayamam / I Cannot Live Without You (1977) tells the story of a businesswoman who hires a professional killer when she learns that she is mortally ill and subsequently falls in love with him.

\section{Ertuğrul, Muhsin (b. 1892, Istanbul, Turkey; d. 1979, Izmir)}

In the first years of the Republic film production was monopolized by a single man: Ertuğrul. He was an actor / director with international connections who came to be remembered as 'the father of Turkish cinema'. He had worked in Germany and the former USSR, and made friends with the celebrities of the film and theatre worlds (he even brought Greta Garbo and Mauritz Stiller to Turkey for one film production). In Germany he directed and acted in three films: Samson (1920), Das Fest der Schwarzen Tulpe / The Black Tulip Festival (1921) and Die Teufelsanbeter / Devil Worshippers (1921). He returned to Turkey and began to work for the first private studio, Kemal Film, founded by the brothers Kemal and Şakir Seden in 1922. The first films he made in Turkey are important because, for the first time in the history of Turkish cinema, Muslim women appeared on the screen (Bedia Muvahhit, Neyyire Neyir). As the director of Municipal Theatre of Istanbul, Ertuğrul staged plays during the winter that he would be able to film during the following summer. His most successful films were Ateșten Gömlek / Shirt of Fire (1923), an adaptation from the female novelist Halide Edib; Bir Millet Uyaniyor / A Nation is Awakening (1932), in which Atatürk 
(the President and the Founder of the Republic) and General Kazım Özalp played small roles; Batakl Damın Kızı Aysel / Aysel, the Daughter of the Swampy House (1934), adapted from a Lagerlof novel and creating the atmosphere of Russian rural dramas; and Bir Șehvet Kurbanı / Victim of Lust (1940), a remake of Victor Fleming's The Way of All Flesh. He made Istanbul Sokaklarinda / In the Streets of Istanbul (1931), the first co-production (Turkish, Egyptian and Greek) and post-sync film (it was dubbed in Paris). Spartakus (1926), which he made in the USSR, is considered by Jean Mitry the first revolutionary epic, but an average work. Ertuğrul also won the first international prize for Turkish cinema with a remake: Leblebici Horhor A $\breve{g}$ a / Lord Leblebici Horhor (1934), which he first shot in 1923. It was awarded the diploma of honour at the second Venice International Film Festival in 1934, although the film failed at the box office. His Halıcı $\mathrm{K}_{l} z$ / The Carpet Weaver (1953) was the first Turkish colour film to be exhibited, although it was Ali İpar's Salgin / The Plague (1952) that was the first film shot on colour stock (Salgin was not released until 1954 because of a two-year wait in film laboratories in the United States). Halici Kiz was not well received by the audience, which brought his career in cinema to an end. Film critics and historians have criticized Ertuğrul, not only for his monopolization of Turkish cinema from 1922 to 1939 , but also for his lack of a sense of cinematography. It is true that Ertuğrul was not a committed cinematographer; however, his camera set-ups and editing show some effort to develop a specifically cinematic language.

\section{Güney, Yılmaz (b. 1931, Adana, Turkey; d. 1984, Paris)}

Güney, the legendary actor-director of Turkish cinema, was able to break free from the restrictions of Yeșilçam, while establishing a longstanding relationship with the audience. The roles he played in Ben Öldükçe Yașartm / I Live as Long as I Die (Duygu Sağıroğlu, 1965), Hudutların Kanunu / The Law of the Borders (Akad, 1966) and Kurbanlık Katil / The Murderer is the Victim (Akad, 1967) brought him fame. He was particularly admired by lower middle-class audiences in Anatolia. He was given the epithet 'Ugly King', thus shaking the reign of the jeune premier as the male lead character. Umut / Hope (1970), which opened the doors of international reputation to him, tells the story of a cab driver desperately seeking treasure said to be buried in the country and ending up in lunacy. As a devout Marxist, Güney's films tended towards socialist realism. He related the problems which he exposed in his films to social injustice and its economic underpinnings and, as Roy Armes has put it, showed the 'failure of the individual acting alone' (Armes 1981: 10). He used elements familiar from melodrama to strengthen the total effect of his films. In Baba / The Father (1971), the eponymous father accepts the blame for a crime committed by his boss' son and is put in prison. When he is released, he searches for the members of his family, which had broken up years ago, running into his daughter in a brothel and in the end being killed by his son. Arkadaș / Friend (1974) is another sensational film, contrasting the idealist engineer Âzem (played by Güney himself) with his classmate Cemil (Kerim Afșar), who represents the corrupt and malfunctioning bourgeoisie. Güney, who had been repeatedly in prison on the charge of spreading communist propaganda, was convicted of murder in 1974 after killing the judge Safa Mutlu in Yumurtalık in Adana as the result of an unfortunate argument. In prison, he wrote the scripts for three films that were directed by others: Sürü / The Herd (Zeki Ökten, 1978), Düșman / Enemy (Ökten, 
1979) and Yol/ The Way (Șerif Gören, 1981), probably the best-known Turkish film in the West. Yol, a drama about five prisoners who go on leave from prison and find that the world outside is no better than life inside, bears resemblance to Güney's own life after shooting was completed: he took leave from prison and never returned. Güney edited Yol in France and shared the Grand Prix at Cannes with Costa Gavras in 1982. In 1983 he lost his Turkish citizenship. His last film Le mur / Duvar / The Wall (1983), another bleak prison drama, was produced in France, where he died in 1984.

Gürses, Muharrem (b. 1913, Amasya, Turkey; d. 1999, Istanbul)

Gürses is a director of the 1950s who is noteworthy for developing an indigenous version of melodrama. He exercised his craft by exploiting the formulas of a genre ('Gürses melodramas') that was attached to his name for more than a decade. Between 1952 and 1988 he made some eighty-two films that remain untouched by academic

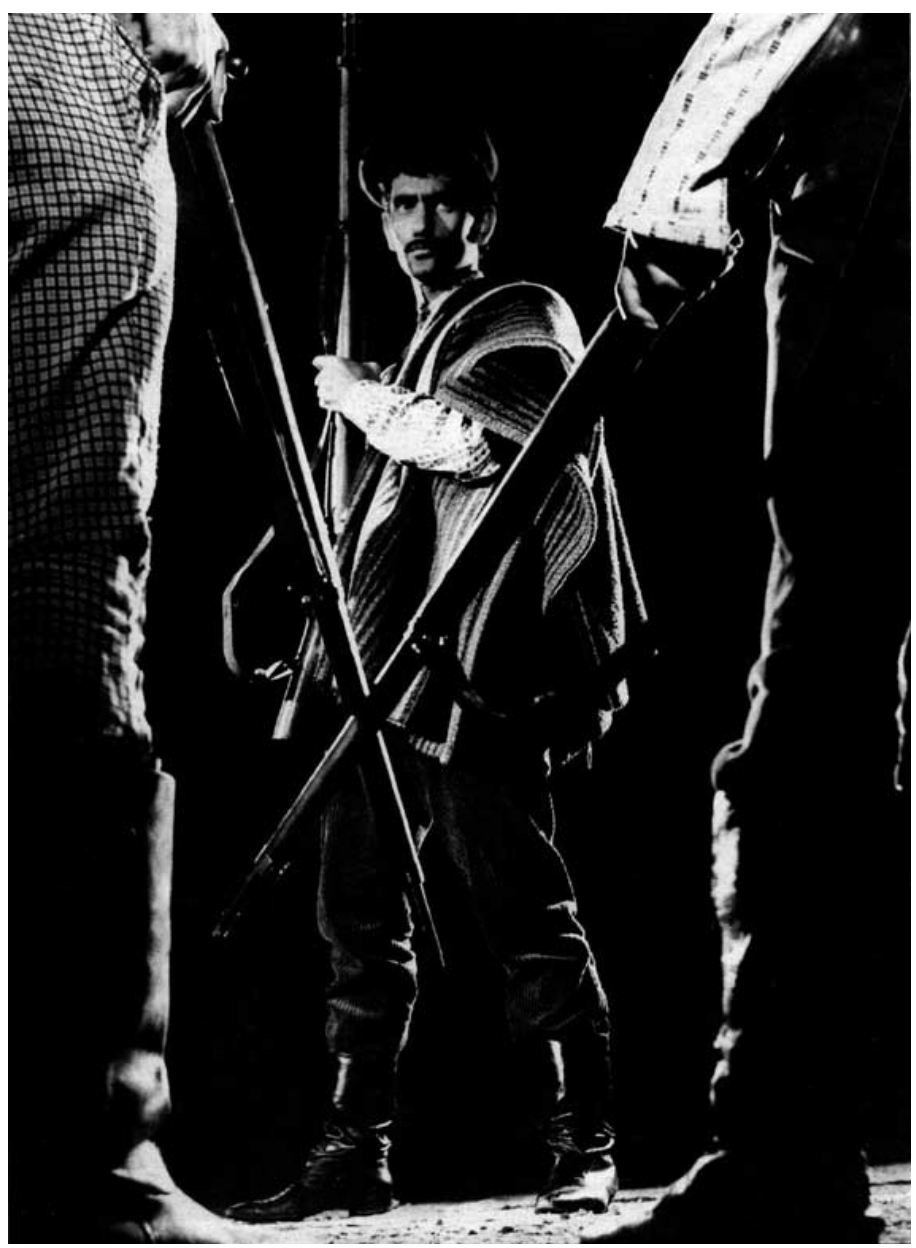

Figure 57 Y1lmaz Güney: the legendary figure of Turkish cinema 
research. Gürses mainly directed rural and small-town melodramas, historical and religious films, all of which were extremely popular with audiences because of his excessively tragic tone. They include Zeynep'in Gözyașları / The Tears of Zeynep (1952), İhtiras Kurbanlarl / Victims of Lust (1953), Gülmeyen Yüzler / Stern Faces (1955) and Yetimler Ahı / The Cry of the Orphans (1956).

\section{Heper, Alp Zeki (b. 1939, Istanbul, Turkey; d. 1984, Istanbul)}

Heper, who was an exemplary case of the tormented artist and failed genius, graduated from the Institut des Hautes Etudes Cinématographiques in France. His short films (Bir Kadın / A Woman and Şafak / Dawn) won awards from IDHEC and the Ministry of Culture of Austria. After his return to Turkey he worked as an assistant to Akad. He began to direct films for his own company in 1964. His first feature-length film, Soluk Gecenin Așk Hikayeleri / Love Stories of a Pale Night (1966), heavily influenced by surrealism, was banned by the censors and never commercially exhibited. After that, he made some more commercial films (Dolmuș Şoförü / Dolmuș Driver, 1967; Eșkiya Halil / Halil the Bandit, 1968; Kara Battal'ın Actsı / The Agony of Black Battal, 1968), but ultimately failed to achieve success. His unstable mental condition led him to isolation and distress. According to his will, Heper's films cannot be distributed and may be screened for audiences of no more than three people.

\section{Kavur, Ömer (b. 1944, Ankara, Turkey)}

Kavur is probably Turkey's most philosophical film-maker. He went to France after secondary school, graduated from the Conservatoire Indépendent du Cinéma Français and took a Master's degree in film history at the Sorbonne, as well as a degree in social sciences at the Institut des Hautes Etudes du Journalisme. He also worked as an assistant to Bryan Forbes and Alain Robbe-Grillet. After his return to Turkey, he first made documentary films: Istanbul, Atatürk ve Ankara / Istanbul, Atatürk and Ankara and İzmir ve Boğaziçi Köprüsü / Izmir and the Bosphorus Bridge. In 1974 he directed his first long feature, Yatık Emine (1974), based on a novel by Refik Halid Karay. After a five-year pause, he started directing again and worked with Atıf Yilmaz on some joint projects. In 1978, he established his own independent production company Alfa Film and has since produced his own films: Yusuf ile Kenan / Yusuf and Kenan (1979), Ah Güzel İstanbul / Oh, Beautiful Istanbul (1981), Kırık Bir Așk Hikayesi / A Broken Love Story (1981), Göl / The Lake (1982), Körebe / Blind Man's Buff (1985) and Amansiz Yol / Hard Way (1986). His Anayurt Oteli / Motherland Hotel (1987), based on a novel by Yusuf Atılgan, is one of the most original literary adaptations of Turkish cinema, filmed in a style that might best be described as magical realism. Anayurt Oteli received various awards at international festivals, including the Fiparesci International Screenwriters' Award at the Venice Film Festival. Gece Yolculuğu / Night Journey (1987) is a self-reflexive film about a screenwriter who runs into a creative crisis. Gizli Yüz / The Hidden Face (1990) was based on a scenario by Orhan Pamuk and continued along the lines of Anayurt Oteli in depicting a dream-like reality, albeit not quite as successfully as its predecessor, appearing slightly contrived, static and uncinematic at times. It got controversial responses, but once again won awards at various international festivals (including the best film award at both the New Cinema 
Festival in Montreal and the Istanbul Film Festival). Akrebin Yolculuğu / Clock Tower (1997) explored the philosphical dimensions of time.

\section{Kıral, Erden (b. 1942, Gölcük, Turkey)}

Kiral graduated with a degree in ceramics from the Academy of Fine Arts in Istanbul. He wrote about cinema in various journals and worked as an assistant to Osman F. Seden, Bilge Olgaç and Y1lmaz Güney. He also worked for television stations, directing commercials. After making some short films (Kumcu / The Sound Seller, Unutulmușlar / The Forgotten People, Hașhaș / Poppy), he directed his first long feature Kanal / Canal (1978). Bereketli Topraklar Üzerinde / On Fertile Soil (1979) followed. His films tend to focus on the harsh experiences of rural people, attempting to render these from a modern perspective. Kiral lived in Berlin for some years. His Hakkari'de Bir Mevsim / A Season in Hakkari (1982), the story of a school teacher who spends a winter teaching in a very poor village in eastern Turkey, was awarded the special jury prize at the Berlin Film Festival in 1983. Ayna / Mirror (1984) also received awards at international festivals in Luxembourg, Portugal and Istanbul. Further films were Dilan (1986) and Av Zamanı / Hunting Time (1987). His Mavi Sürgün / The Blue Exile (1993), based on the autobiography of the 'Fisherman of Halikarnassos' Cevat Șakir Kebaaḡaçl, was heavily funded by Eurimages. The film begins promisingly with documentary footage depicting Turkey after World War I, but develops into a rather lengthy and melodramatic exploration of the male artist's problematic psyche and the healing powers of rural life.

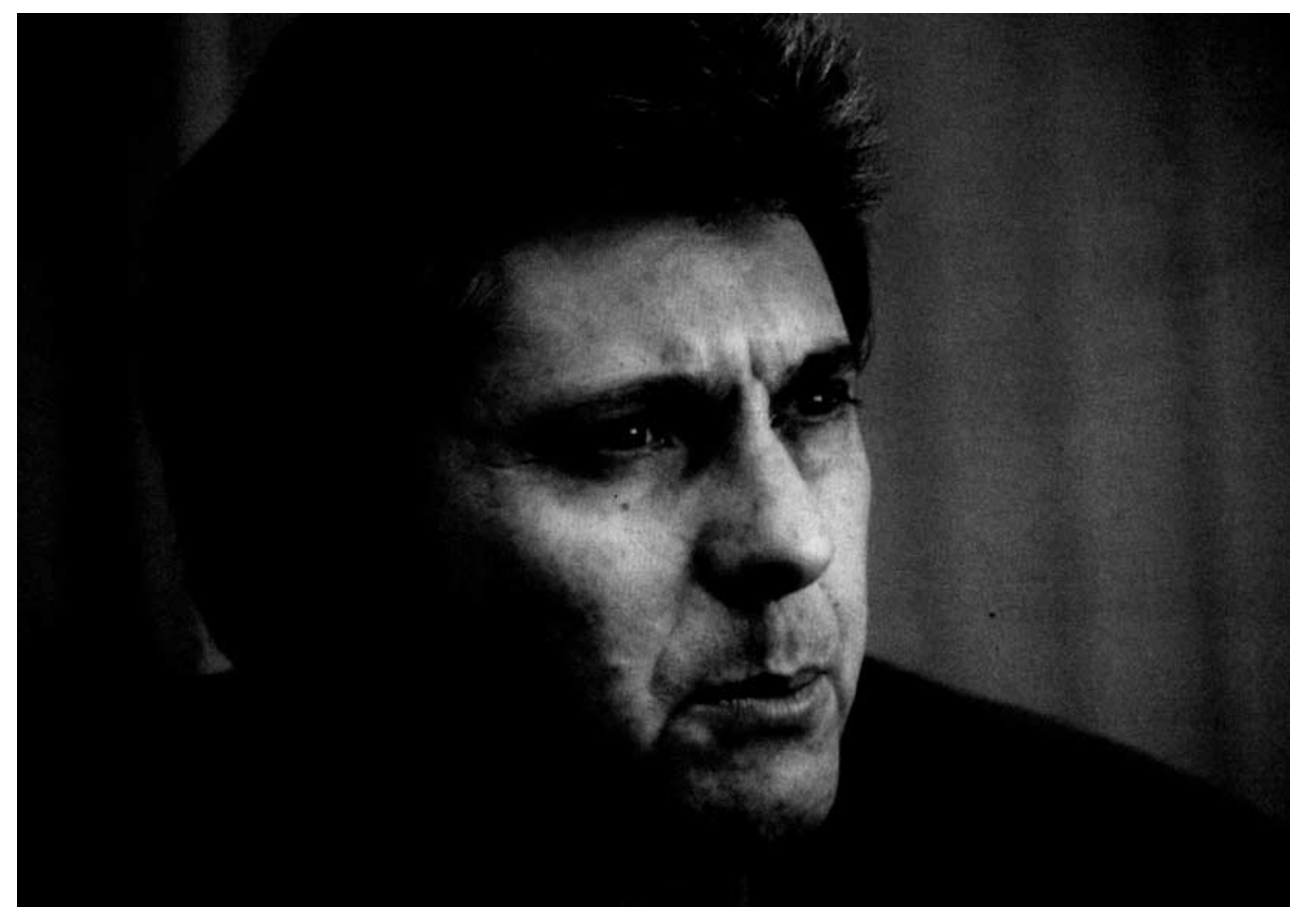

Figure 58 Ömer Kavur: the philosophical mind of Turkish cinema 
Refiğ, Halit (b. 1934, Izmir, Turkey)

Champion and theoretician of a 'national cinema', Refiğ first wrote film reviews and screenplays, and then made his first film, Yasak Așk / Forbidden Love, in 1961. His Gurbet Kuşları / Birds of Exile (1964), which focuses on the sufferings and dissolution of a family in the big city, is now regarded as a classic. He made films in a wide range of genres: social realism (Șehirdeki Yabanci / A Stranger in Town, 1962; Gurbet Kușlart), folk and fairy tales (Atsız Cengaver / A Warrior without a Horse, 1970; Leyla ve Mecnun / Leila and Majnun, 1982), historical 'costume' dramas (Haremde Dört Kadın / Four Women in the Harem, 1965; Çöl Kartalı / Desert Eagle, 1972) and melodramas (Sevmek ve Ölmek Zamanı / Time to Love and Time to Die, 1971; Fatma Baci, 1972). He developed an indiviual style, which gave added impact to his narratives. He ably handled the most topical stories (such as drug addiction in Beyaz Ölüm / Death in White, 1983), as well as the most psychological ones (the young woman going mad in Teyzem / My Auntie, 1986; Köpekler Adasl / The Isle of Dogs, 1997).

\section{Turgul, Yavuz (b. 1946, Istanbul, Turkey)}

Turgul began to work as a screenwriter for Ertem Eğilmez in 1976. He made his name writing screenplays for a number of directors who followed the tradition of Eğilmez. His scripts included Sultan (Kartal Tibet, 1978), Çiçek Abbas / Abbas in Flower (Sinan Çetin, 1982) and Zügürt Ăga / The Penniless Lord (Nesli Çölgeçen, 1986). He made his directorial debut with Fahriye Abla / Sister Fahriye (1984), telling the story of a young girl going through stages of emancipation. His Muhsin Bey / Mr Muhsin (1986) and Așk Filmlerinin Unutulmaz Yönetmeni / The Unforgettable Director of Romantic Movies (1990) focus on the theme of a solitary man who cannot catch up with socio-cultural change. Mr Muhsin is a music producer whose ambition of preserving Turkey's cultural heritage prevents him from making a living. Hasmet Asilkan, the eponymous unforgettable director of romantic movies, makes a political film in order to get the plaudits of the intellectual elite, but goes bankrupt. Turgul's Eșkiya / The Bandit (1997) is a phenomenal film. It was screened for more than twelve months all over Turkey, beating films from the United States (including the much admired Braveheart). It stirred heated discussions about the possibility of Turkish cinema winning its audience back.

\section{Ustaoğlu, Yeșim (b. 1960, Sarıkamıș, Turkey)}

Ustaoğlu is one of the promising new women directors of Turkish cinema. She studied architecture at Karadeniz Technical University and took a post-graduate degree at Y1ldiz University in Istanbul. She wrote articles on cinema in various art journals, and started her career in film-making with the short films Bir Anı Yakalamak / To Catch a Moment (1984), Magnafantagna (1987), Düet / Duet (1990) and Otel / Hotel (1992). Her first feature was $\dot{I} z$ / The Trace (1993), a detective film with a twist and somewhat surreal elements. Her latest film, Güneșe Yolculuk / Journey to the Sun (1999), the story of a Turkish-Kurdish friendship, was awarded the Peace Prize and the Blue Angel Prize at the Berlin Film Festival. 


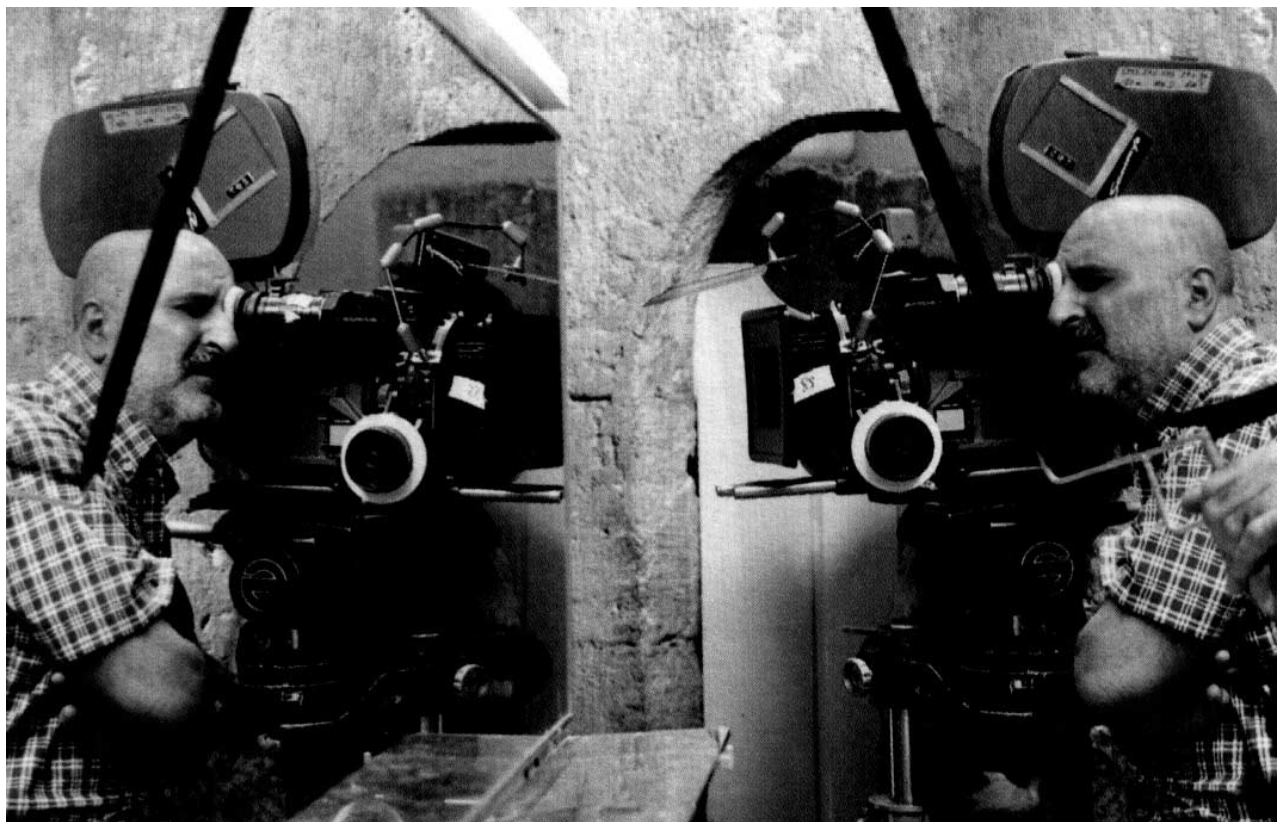

Figure 59 Yavuz Turgul: the revival of Turkish popular cinema?

\section{Yllmaz, Atıf (Batibeki) (b. 1926, Mersin, Turkey)}

Y1lmaz began his directing career in 1952 with Kanl Feryat / The Bloody Lament. Director of some 110 films and winner of more than twenty awards, he mastered his craft in a wide range of genres (melodrama, children's films, policiers, psychological films, historical 'costume' dramas, epics) and textual modes (realism, fantasy). Y1lmaz is called the 'youngest film-maker of Turkish cinema' for his continuous search for new themes and stylistic innovations, although he has never concealed his concern for commercial success. In Yedi Kocalı Hürmüz / Hürmüz with Seven Husbands (1971), he attempted the risky task of reviving the visual style of miniature paintings with the narrative running with the rhythm of classical Turkish music; Ne Olacak Simdi? / What Now? (1979) and Asiye Nastl Kurtulur / How to Save Asiye (1986) are exemplary studies in Brechtian alienation effects; the women of Mine (1982) and Bir Yudum Sevgi I A Sip of Love (1984) dare to violate the norms of society in order to meet their need for love and even sexual desire; Adr Vasfiye / Vasfiye is Her Name (1985) and Aaahh, Belinda! / Oh, Belinda! (1986) question the ways in which the concept 'woman' is constructed and represented in the media; Düş Gezginleri / Dream Wanderers (1992) depicts a lesbian relationship ruined by power games; and his latest film Nihavent Mucize / Miracle Ma Non Troppo (1997), co-funded by Eurimages and starring once again Türkan Șoray, is an anti-œdipal comedy about a beautiful woman who returns from the dead to prove to her son that she is really no different from other women. 


\section{List of actors}

\section{Ar, Müjde (b. 1954, Istanbul, Turkey)}

Formerly a stage actress and fashion model, Ar was seen as a more sensual version of Türkan Şoray: straightforward and challenging, but still reserved. She first appeared as the lustful young wife of an old man in a television serial (Halit Refiğg $A s ̧ k-l$ Memnu / Forbidden Love, 1974) and continued to play film roles with a strong emphasis on her sexuality. Ar became a sex symbol and eventually a bankable star in the mid-1970s, an advantage which was to be enjoyed by film-makers even in post1980 films that focused on problems of sexuality or the representation and cultural role of women. She played a woman enslaved to the perverse fantasies of her husband (Asilacak Kadın / The Woman to be Hanged); the bourgeois prostitute in a parody of Buñuel's notorious Belle de Jour (Maça Kızı / Queen of Spades); the victim of her own family (Teyzem / My Auntie); the high-society prostitute fallen prey to the illusion that she has found the love of her life (Dağınık Yatak / The Unmade Bed); the mature widow who cannot break the sexual spell of a male chauvinist (Dul Bir Kadin / A Widow); a woman as constructed by the fantasies of the men in her life (Adl Vasfiye / Vasfiye is Her Name); and a working girl fascinated by the possibilities of voyeurism (Gizli Duygular / Secret Feelings).

\section{Arkın, Cüneyt (b. 1937, Eskișehir, Turkey)}

When he first appeared in the movies, Arkın played the naïve and handsome young man. He was either deceived and exploited by the lead female character or loved by a powerful city girl who was fed up with the spoilt men around her (Halit Refiğg, Gurbet Kușları / Birds of Exile, 1964; Ülkü Erakalın, Gözleri Ömre Bedel/ Her Eyes are Worth a Life, 1964; Nuri Ergün, Fakir Bir Gencin Romanı / The Story of a Poor Young Man, 1965; Ülkü Erakalın, Ayrılık Sarkısı / A Farewell Song, 1965). As he grew older, he began to play the rich rascal who fell for the naïve and poor girl (Așk Mabudesi / Love Goddess, 1969). He is now primarily remembered for his superhero roles in cop series (Cemil, 1975; Cemil Dönüyor / Cemil Returns, 1977) and historical action movies, some of which are adaptations of popular comics (Hacı Murat, 1967; Hacı Murat Geliyor / Hacı Murat is Coming, 1968; Hacı Murat'in Intikami / The Revenge of Hacı Murat, 1972; Kara Murat, 1972; Kara Murat Devler Savaşıyor / Kara Murat: Titans Clash, 1978; Kara Murat Fatih'in Fermanı / Kara Murat: The Order of Fatih the Conquerer, 1973; Kara Murat Kara Șövalyeye Karșı I Kara Murat against the Black Knight, 1975; Malkoçoğlu, 1966; Malkoçoğlu Kara Korsan I Malkoçoğlu, Black Pirate, 1968).

\section{Alışık, Sadri (b. 1925, Istanbul, Turkey; d. 1995, Istanbul)}

Alıșik is noteworthy for his roles as the ordinary man on the street who can be dangerously daring when necessary. His character is self-contained and leads a moderate life until something (mostly a woman in need or a child to be taken care of) knocks him off balance (Ah Güzel İstanbul / Oh, Beautiful Istanbul, 1966). In this sense he is very Chaplinesque; however, his characters like to make speeches about the virtues of honesty and a simple life when they are defeated, and lack the economy of Chaplin's minimalist expressions. Just like many other Turkish actors who feel at home with both melodrama 
and comedy, Alıș1k made some very popular comedies: the Turist Ömer / Ömer the Tourist series (between 1964-71) being the most successful among them.

\section{Ișık, Ayhan (b. 1929 Izmir; d. Istanbul 1979)}

Ișık was the first male star of Turkish cinema, playing the lead role in the early films of Akad. His handsome looks and good performances in Kanun Namina / In the Name of the Law, Öldüren Șehir / Murderous City and Üç Tekerlekli Bisiklet / Tricycle put him in a position to arrange contracts according to his own rules, a sign of stardom and an example that was soon followed by other actors and actresses. Initially he established himself as the serious character who falls prey to the snares of women or society by, for example, risking his life for his homeland. In later years, however, he played a range of diverse characters: a witty chauffeur driving and taming the lady of the house (Nejat Saydam, Küçük Hanımın Şoförü / Little Lady’s Chauffeur, 1962); a smart and chivalrous thief (Safa Önal, Cingöz Recai / Shrewd Recai, 1969). In the early 1970s, he sought international roles, but was only able to make cut-price horror films. He co-starred with Richard Harrison in Lamico del Padrino / The Godfather's Friend aka The Revenge of the Godfather (Frank Agrama, 1972) and with Klaus Kinski in both La Mano che Nutre I The Hand that Feeds Death (Sergio Garrone, 1974) and Le Amanti del Mostro / The Love of the Monster (Garrone, 1974).

\section{Koçyiğit, Hülya (b. 1947, Istanbul, Turkey)}

Koçyiğit first studied theatre and ballet, before winning a contest organized by a film magazine in 1963 and making her debut in Metin Erksan's classic Susuz Yaz / Dry Summer (1963). She also played in the prestigious Akad trilogy (Gelin / The Bride, Dügün / The Wedding, Diyet / Blood Money, 1973-4). One of the four first actresses of Turkish popular cinema (along with Türkan Șoray, Fatma Girik and Filiz Akın), she is distinguished from the others by her relatively more academic performances. In contrast with Şoray, for example, Koçyiğit skilfully orchestrates her facial features in a slightly self-conscious manner.

\section{Șen, Șener (b. 1942, Adana, Turkey)}

Coming from the theatre, Șen attracted attention as the neurotic physical trainer in the Hababam ... / Carry On ... series. He soon began to play the lead in comedies. Șen is able to play completely opposite characters: the civil servant who cannot cope with the demands of his social environment (Namuslu / Honourable, 1984) or the sneaky driver who can easily exploit his devout assistant (Çiçek Abbas / Abbas in Flower, 1982). His strength lies in the way he keeps a balance between the comic and melodramatic. His collaborations with Yavuz Turgul (former scriptwriter to Eğilmez) made him an established star, mostly acting as an agent of resistance against social and cultural corruption: a manager, himself a fan of Turkish classical music, who is forced to produce a trashy music album (Muhsin Bey / Mr Muhsin); an impoverished feudal lord who has to migrate to Istanbul and ends up in the streets selling food (Zügürrt A $\breve{g} a$ / The Penniless Lord); a popular film director who attempts to make an art film in order to be approved by the cultural elite but fails in the attempt (Aşk Filmlerinin Unutulmaz 
Yönetmeni / The Unforgettable Director of Romantic Movies); a stand-up comedian who is determined to become rich at all costs but cannot leave his friends (Gölge Oyunu / Shadow Play); a noble bandit from south-eastern Turkey who gets lost in the jungle of the big city (Eșkiya / The Bandit).

\section{Sonku, Cahide (b. 1916, Yemen - part of the former Ottoman Empire; d. 1981 Istanbul)}

Muhsin Ertuğrul introduced the first star of Turkish cinema: Sonku, a peroxide blonde from Yemen who quickly became a cult figure in high society. She played a wide range of roles in her films: fallen angels (Aysel Bataklı Damin Kızı / Angel from the Swamps, 1934), femme fatales (Șehvet Kurbanı / Victim of Lust, 1940) and, in later years, affectionate mothers (Beklenen Sarkı / The Expected Song, 1953). However, she is now better remembered for the way in which her star persona was overshadowed by images of a scandalous later life (failed marriages, alcoholism, poverty and even homelessness).

\section{Șoray, Türkan (b. 1945, Istanbul, Turkey)}

The icon of melodramas and 'Sultaness of Yeșilçam', Șoray started her acting career in the early 1960s. Her clumsy and tomboyish manners in the early films were transformed after she lost weight, changed her hairstyle and had cosmetic surgery on her nose. Still well-built, but elegant and swift, she felt at home in diverse roles, ranging from a jubilant gypsy girl with a certain degree of eroticism (Ülkü Erakalın, Hapisane Gelini / The Jail Bride, 1968) to a virtuous lady determined to keep faith in her husband (Safa Önal, Bir Kadın Kayboldu I A Woman Vanished, 1973). Her characters, however, had to obey the rules of chastity. She was seldom seen kissing a man on screen and she never deceived her lover / husband; even when she was involved in a non-matrimonial act, this was only implied (never shown) to serve as a pretext for having children (Nejat Saydam, Ayșem / Ayshe Mine, 1968). After the 1980s, she changed her star image. Her characters were now more sexually active. There has even been a change in her acting: the slightly exaggerated facial expressions (movement of eyes, the use of lips and eyebrows), which were perfectly in harmony with the style of melodrama, are now controlled by an economy of realism. Şoray has also directed some films: Dönüş / The Return (1972), Azap / Suffering (1973), Bodrum Hakimi / The Ruler of Bodrum (1976) and Yılanı Öldürseler / Kill the Snake (1981).

\section{Sunal, Kemal (b. 1944, Istanbul, Turkey; d. 2000 Istanbul)}

Sunal is one of the most popular stars of Turkish cinema and television. Television channels repeatedly show his films, and he completed a master's thesis on the sources of his popularity. Like many other comedy stars, he first appeared on stage. Sunal then played the unforgettable half-wit character Inek Șaban in the Hababam ... / Carry On ... series. His performances rely heavily on the possibilities of his face (he once said that he felt lucky because he was ugly) and the vulgar use of language. Following Hababam ... he played the lead role in the S,aban series. S,aban is a character type inspired by the folktale hero Keloğlan: he is poor, powerless and society looks down on him, but in the end he defeats powerful enemies who have attempted to abuse his good will. 


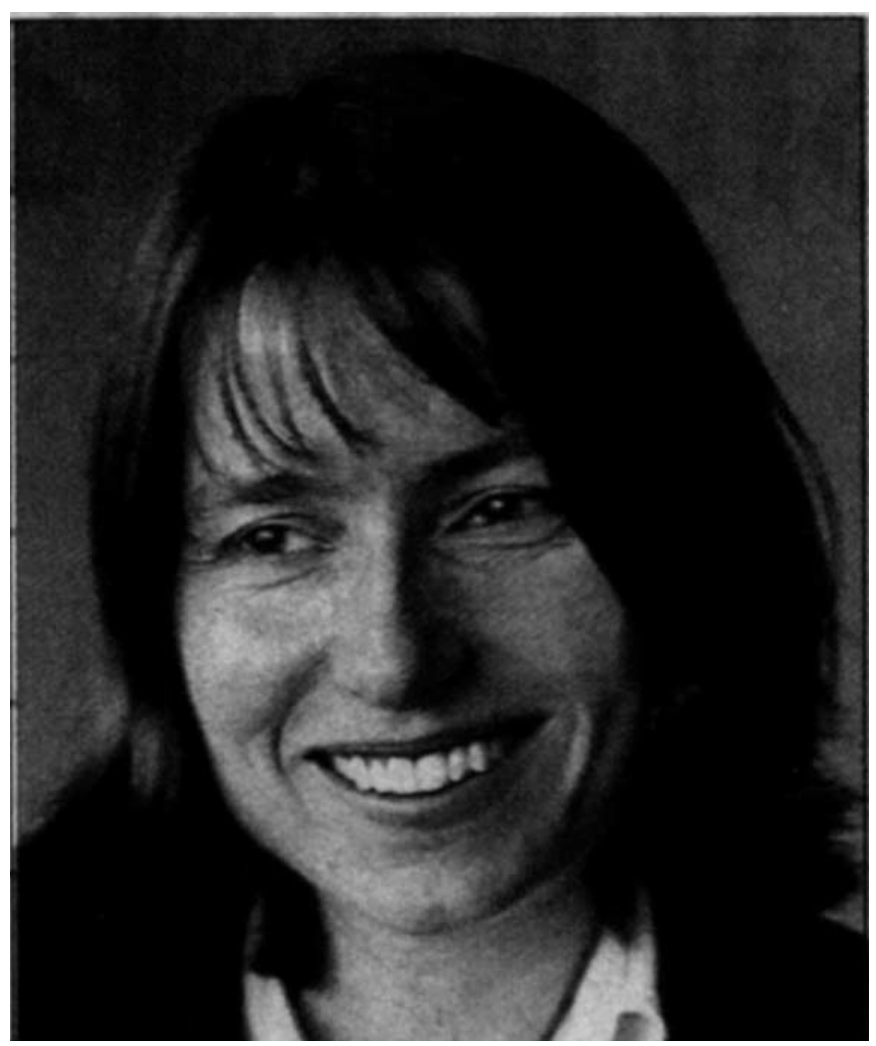

Figure 60 Yeşim Ustaoğlu - architect turned film maker

\section{List of institutions}

\section{University programmes}

Anadolu Üniversitesi, İletișim Fakültesi, Sinema-TV Bölümü

26470 Eskișehir

Phone: + +902223350581

Fax: $\quad$ +902223204520

B.A. programme in English

Ankara Üniversitesi, İletișim Fakültesi, Radyo-TV-Sinema Bölümü

Cebeci, Ankara

Phone: $\quad+903123197714$

Fax: $\quad+903123622712$ 
Turkish Cinema 569

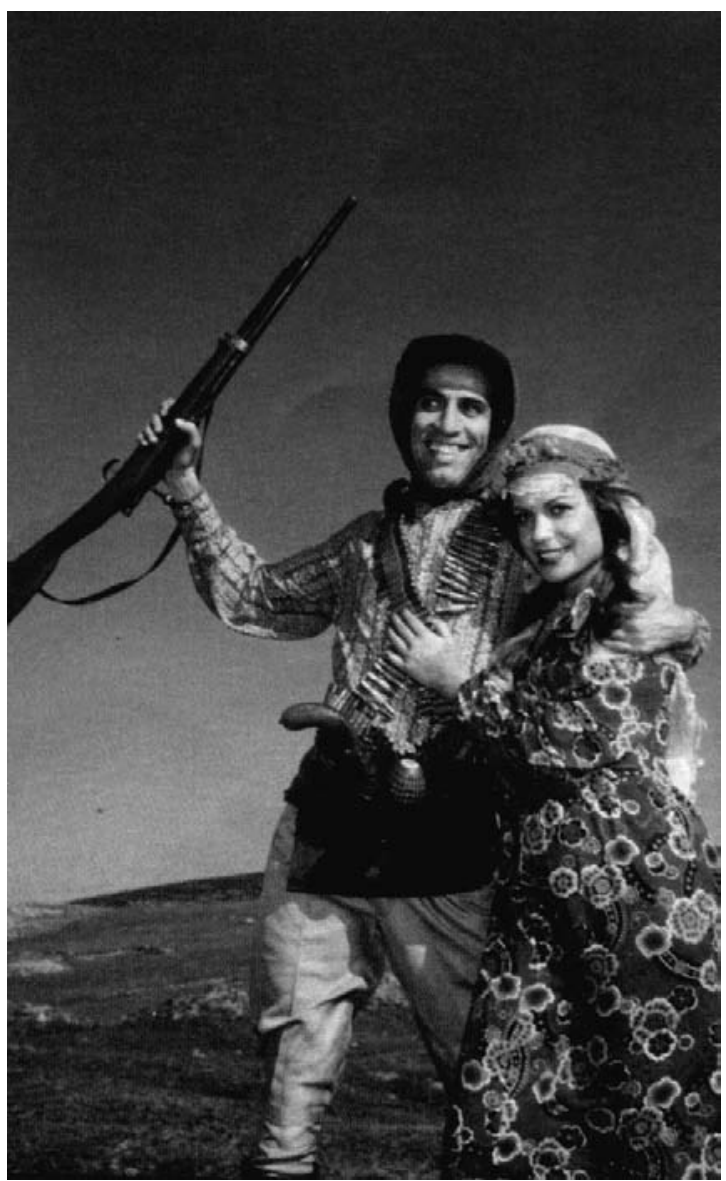

Figure 61 Kemal Sunal: the village idiot pointing the way to resistance

Dokuz Eylül Üniversitesi, Güzel Sanatlar Fakültesi, Sinema-TV Bölümü

Șehitler cad. no. 12, Alsancak, İzmir

Phone: $\quad+902324213647$

Fax: $\quad$ +904215720

Gazi Üniversitesi, İletișim Fakültesi, Sinema-TV Bölümü

Ankara

Phone: $\quad$ +903122126495 
İstanbul Bilgi Üniversitesi, Sinema-TV Bölümü

İnönü cad. no. 28, Kuștepe 80310, Șișli-İstanbul

Phone: $\quad$ +902122162222

Fax: $\quad$ +902122162400

Website: http://ibun.edu.tr

Offers graduate programmes in English

İstanbul Üniversitesi, İletișim Fakültesi, Radyo-TV-Sinema Bölümü

Vezneciler, İstanbul

Phone: $\quad+902125125257$

Fax: $\quad$ +902125269194

Marmara Üniversitesi, Güzel Sanatlar Fakültesi, Sinema-TV Bölümü

Haydarpasa Kampüsü, İstanbul

Phone / fax: $\quad$ +902163368424

Mimar Sinan Üniversitesi, Sinema-TV Merkezi

K1șlaönü, 80700 Beșiktaș, İstanbul

Phone: $\quad$ +902122749870,2670494

Fax: $\quad$ +902122116599

\section{Organizations}

GISAM ( Görsel Ișitsel Sistemler Araștırma ve Yayınlama Merkezi / AudioVisual Systems Research Centre)

Orta Doğu Teknik Üniversitesi 06531 Ankara

Phone: + +903122102934

Fax: $\quad+903121327$

SE-SAM (Türkiye Sinema Eseri Sahipleri Meslek Birliği / Turkish Producers Organization) and TÜRSAV (Türk Sinema Vakf / Turkish Cinema Foundation)

İstiklal cad. 122 / 4, Beyoğlu İstanbul

Phone: $\quad+902122454645$

Fax: $\quad$ +90212 $\quad$ + 2452747

TÜRSAK ( Türkiye Sinema ve Audiovisuel Kültür Vakfl / Turkish Foundation of Film and Audiovisual Culture)

Gazeteci Erol Dernek sok. 11 / 2 Hanif Han 80072, Beyoğlu İstanbul

Phone: $\quad$ +902122445251/25167

Fax: $\quad$ +902122920337 
T.C. Kültür Bakanlı̆gl, Telif Hakları ve Sinema Müdürlüğ̈̈ / The Ministry of Culture, Directorate of Copyrights and Cinema

Necatibey cad. 55 / 5, Necatibey, Ankara

Phone: $\quad+903122317962$

Fax: $\quad$ +903122319694

\section{Archives}

Mimar Sinan Üniversitesi, Sinema-TV Merkezi, a member of FIAF, has the largest film archive. The Film Department (Sinema Dairesi) of the Ministry of Culture in Ankara keeps a video copy of the films that it sponsored. TÜRSAK can also provide video copies, as well as documents and other archive materials. The film and television departments of universities run small archives with limited facilities.

\section{International festivals}

Ankara Uluslararası Film Festivali / Ankara International Film Festival

Dünya Kitle İletișim Vakfı, Dünya Ticaret Merkezi, Tahran cad. no. 30, 06700 Ankara

Phone: $\quad$ +90 $\quad$ 31246838 92-4687745

Fax: $\quad$ +90312467 $\quad$ +9830

Avrupa Filmleri Festivali / Festival of European Films

Bülten sok. no. 13, Kavaklidere Ankara

Phone: $\quad+903124687140$

Fax: $\quad+903124687139$

İstanbul Uluslararası Film Festivali / International Istanbul Film Festival

İstanbul Kültür ve Sanat Vakfı, İstiklal cad. 142 Luvr apt, Beyoğlu İstanbul

Phone: $\quad$ +90212 $\quad$ +9033133

Fax: $\quad+902122497771$

İstanbul Uluslararası Kisa Film Festivali / International Istanbul Short Film

Festival

İFSAK, Ayhan Ișık sok, Özverim apt 34 / 2, Beyoğlu İstanbul

Phone: $\quad$ +90212 $\quad$ +9021401

Fax: $\quad$ + $\quad$ 902122524461 
İmir Uluslararası Film Festivali / International Izmir Film Festival

Oğuz Makal, Dokuz Eylül Üniversitesi, Güzel Sanatlar Fakültesi, Șehitler cad. no. 12, Alsancak, İzmir

Phone: $\quad$ +902324213647

Fax: $\quad$ +902324215720

\section{London Turkish Film Festival}

Rio Cinema, 107 Kingsland High Street, London E8, England

Phone: $\quad$ +4402072546677

\section{References and further reading}

Abisel, N. (1994) Türk Sineması Üzerine Yazılar, Ankara: İmge.

Armes, R. (1981) 'Yllmaz Güney: The limits of individual action', Framework, 15-17 (summer): 9-11.

Coş, N. (1969) 'Türkiye 'deli Sinemalarin Dağıllışı ve Bu Daḡısın Sebepleri', As Sinema Dergisi 2: 12.

Cullingworth, M. (1989) 'On a first viewing of Turkish cinema', in C. Woodhead (ed.) Turkish Cinema: An Introduction, London: SOAS, pp. 11-18.

Derman, D. (1996) 'Mother-daughter relationship in the family melodrama: Teyzem', in D. Derman and Ross, K. (eds) Gender and Media, Ankara: Med-Campus no. A126, pp. 100-15.

Dorsay, A. (1989) 'An overview of Turkish cinema from its origins to the present day', in C. Woodhead (ed.) Turkish Cinema: An Introduction, London: SOAS, pp. 21-33.

Erdoğan, N. (1998) 'Narratives of resistance: National identity and ambivalence inTurkish melodrama between 1965 and 1975', Screen 39, 3 (autumn): 259-71.

Erdoḡam, N. (2001) 'Violent Images: Hybridity and Excess in The Man Who Saved the World', in Medicated Identities, ed. by Karen Ross, Deniz Derman, Nevena Dakovic, Istanbul: Bilgi University Press, pp. 115-129.

Göktürk, D. (2001) "Turkish Delight - German Fright: Migrant Identities in Transnational Cinema", in Medicated Identities (see above), pp. 131-149.

Makal, O. (1994) Sinemada Yedinci Adam: Türk Sinemasında İç ve Dış Göç Olayı, Izmir: Ege.

Mehmet, B. (ed.) (1996) Le Cinema Turc, Paris: Centre George Pompidou.

Nadler, J. (1998) 'Pic Renaissance' and Variety (18-24 May): 61.

Özgüç, A. (1995a) Türk Film Yönetmenleri Sözlüğü, Istanbul: AFA.

- (1995b) 80. Yllinda Türk Sineması 1914-1994 / Turkish Cinema at its 80th Anniversary 1914-1994, Ankara: Ministry of Culture. (In both Turkish and English.) (1997a) Türk Filmleri Sözlüğ̈̈ 1914-1973, Istanbul: SESAM. (1997b) Türk Filmleri Sözlüğ̈̈ 1974-1990, Istanbul: SESAM. -(1997c) Türk Filmleri Sözlüğü 1991-1996, Istanbul: SESAM.

Özgüven, F. (1989) 'Male and female in Yeșilçam: Archetypes endorsed by mutual agreement of audience and player', in C. Woodhead (ed.) Turkish Cinema: An Introduction, London: SOAS, pp. 35-41.

Scognamillo, G. (1990) Türk Sinema Tarihi 1896-1986, vols 1-2, Istanbul: Metis. (Includes a short summary in English.)

TÜRSAK (1994) Sinema Yillı̆g 93 / Film Year Book 93, Istanbul: TÜRSAK. (Includes short summaries in English.) (1995) Sinema Yıllı̆̆ 95-96 / Film Year Book 95-96, Istanbul: TÜRSAK. (Includes short summaries in English.) 
(1996) Sinema Yillığ 96-97 / Film Year Book 96-97, Istanbul: TÜRSAK. (Includes short summaries in English.)

(1997) Sinema Ylllığ 97-98 / Film Year Book 97-98, Istanbul: TÜRSAK. (Includes short summaries in English.) 